\title{
Properties Investigation of GO/HA/Pt Composite Thin Film
}

\author{
Huda F. S. G. Alyafei, ${ }^{1}$ W. Fu, ${ }^{2}$ E. Zalnezhad $\left(\mathbb{D},{ }^{2,3}\right.$ F. Jaber, ${ }^{4}$ A. M. S. Hamouda, ${ }^{1}$ \\ F. Musharavati, ${ }^{1}$ and S. Bae ${ }^{5}$ \\ ${ }^{1}$ Mechanical and Industrial Engineering Department, College of Engineering, Qatar University, 2713 Doha, Qatar \\ ${ }^{2}$ Department of Mechanical Engineering, Hanyang University, 222 Wangsimni-ro, Seongdong-gu, Seoul 133-791, Republic of Korea \\ ${ }^{3}$ Biomechacin LLC, San Antonio, TX 78251, USA \\ ${ }^{4}$ Department of Biomedical Engineering, Ajman University, UAE \\ ${ }^{5}$ Department of Architectural Engineering, Hanyang University, Seoul 04763, Republic of Korea
}

Correspondence should be addressed to E. Zalnezhad; e.zalnezhad@gmail.com

Received 23 February 2019; Revised 23 April 2019; Accepted 22 May 2019; Published 20 June 2019

Academic Editor: Elena Landi

Copyright (C) 2019 Huda F. S. G. Alyafei et al. This is an open access article distributed under the Creative Commons Attribution License, which permits unrestricted use, distribution, and reproduction in any medium, provided the original work is properly cited.

\begin{abstract}
Hydroxyapatite/graphene oxide/platinum (HA/GO/Pt) nanocomposite was synthesized and electrodeposited on a pure zirconium substrate. The coated zirconium was annealed at $200,300,400$, and $600^{\circ} \mathrm{C}$ in vacuum furnace in presence of argon gas. The structure and morphology of the coated samples were characterized. Biocompatibility and wear and corrosion resistances of specimens were examined. The result of corrosion tests shows that the graphene into HA/Pt composites significantly improves their corrosion resistance. The wear tests results of uncoated and coated samples before and after annealing show that coated samples annealed at $300^{\circ} \mathrm{C}$ had better wear resistance compared with uncoated and coated samples at other temperatures. Furthermore, the biocompatibility test shows that the coatings improved the cell attachment and proliferation compared to the pure zirconium substrate.
\end{abstract}

\section{Introduction}

Nowadays, the medical practice uses a large number of implants and devices. Medical devices (blood tubes, artificial hearts, biosensors, and pacemakers) and implants (bone plates, ligaments, joint replacements, heart valves, intraocular lenses, vascular grafts, dental implants, and sutures) are made of biomaterials extensively utilized to restore and/or replace the function of degenerated or traumatized organs or tissues, to correct abnormalities, to improve function, to help in healing, and consequently to improve the patients' quality of life [1].

Today, one of the most challenging tasks for materials science is the development of new biomaterials for medical applications. The necessity of better implants is an obvious need and thus the manufacturing of artificial tissues is highly demanded [2].

Being biocompatible with no toxicity or harm to tissues in the human body is one of the most vital factors that differentiates biomedical materials from other materials. For many years, the development and sustainability of mutually acceptable coexistence of tissues and biomaterials have been of interest to scientists in the field of biomaterials and medical devices users [3].

Concentrations of interstitial fluid and chloride ions in serum are an extremely corrosive environment for biometallic materials. Body fluid (so-called electrolytes) comprised numerous proteins and amino acids that corrode metallic materials. Furthermore, the dissolved oxygen concentration in body fluid is small, which leads to delay the regeneration of the oxide layer on metallic biomaterials, and when the film is detached a large number of metal ions are released $[4,5]$.

Hence, to improve the performance of implants in vitro and in vivo, it is essential to control the interfacial behaviors between the implant and host. Surface treatment can successfully change the chemical and physical properties of the surface of biomaterials to develop the functionalities and properties of the original materials and therefore decrease the opposing interfacial interactions between implants and their surrounding biological environment. For decades, frequent 
surface treatment techniques have been established to eventually upsurge the hemocompatibility and biocompatibility of zirconium based alloys, comprising the deposition of polymer coatings or inorganic thin films (zirconium nitride, diamond-like carbon, zirconium oxide, etc.) and the fabrication of a multifunctional layer for the immobilization of biomolecules using the wet chemical method [6-9]. Considerable progress has been attained in blood compatibility and biocompatibility.

So far, numerous works have been performed to develop bioactivity and corrosion resistance of $\mathrm{Zr}$ and its alloys for biomedical applications utilizing a number of surface modification techniques such as the sol-gel process, chemical or physical vapor deposition, anodization, thermal oxidation, and plasma electrolytic oxidation $[10,11]$.

Hydroxyapatite $(\mathrm{HA})$ with the formula $\mathrm{Ca}_{5}\left(\mathrm{PO}_{4}\right)_{3}(\mathrm{OH})$ is the main mineral composition in human bone and teeth [12] and it is, therefore, a useful bioceramic. The favorable biocompatible properties of hydroxyapatite are well documented. It bonds to bone forming indistinguishable unions and it is rapidly integrated into the human body [13].

A great number of papers are available for dealing with different systems based on graphene oxide, hydroxyapatite, and other composites with the aim to be applicable as biomaterials $[8,14-16]$.

In this study, nanocomposite coating based on HA, reduced graphene oxide, and pure platinum were deposited on zirconium substrates using the electrodeposition technique. The goal was to gain a hybrid ceramic-metal coating, reinforced with graphene oxide that will simultaneously ensure an increase in biocompatibility and corrosion and wear resistances. Surface characterizations were carried out to evaluate the morphology and structure of the coatings using XRD, TEM, SEM, and FTIR.

\section{Experimental Procedure}

Commercially available zirconium substrates of $99.5 \%$ purity (Alfa Aesar, Heysham, England) with dimensions of $40 \times 10 \times$ $0.127 \mathrm{~mm}^{3}$ were used as substrates for electrodeposition. The surface of the zirconium substrate was ground and polished with silicon carbide sandpapers (grit range of 800-1500) and etched in an HF solution for $1 \mathrm{~h}$. Then, it was ultrasonically (Daihan Ultrasonic Bath Set WUC-A02H) cleaned in ethyl alcohol, acetone, and deionized water for $30 \mathrm{~min}$ and lastly dried in a vacuum oven at $70^{\circ} \mathrm{C}$.

Hummers method was used to prepare Graphene oxide [17]. Baradaran et al. used Hummers method for preparation of rGO to investigate the biocompatibility of a nanotube hydroxyapatite-reduced graphene oxide composite [18]. In our work, once GO's synthesis process completed, the suspension was rinsed with dilute $1 \mathrm{M} \mathrm{HCl}$ and deionized water several times to reach a $\mathrm{pH}$ of 5 . The product was separated from the mixture centrifugally at $11,000 \mathrm{rpm}$. Furthermore, to remove unwanted materials from the final product which could affect the biocompatibility of the HA/GO/Pt composite, the $\mathrm{GO}$ was mixed with dd $\mathrm{H}_{2} \mathrm{O}$ and centrifuged five times at $4500 \mathrm{rpm}$ for $10 \mathrm{~min}$. The EDX results detected no trace of other bioincompatible elements used during the Hummers method.

To obtain a golden and transparent GO, $100 \mathrm{ml}$ distilled water was added to $20 \mathrm{ml}$ graphene oxide and mixed thoroughly followed by ultrasonic treatment in double distilled water for $2 \mathrm{~h}$ at $570 \mathrm{~W}$.

To attain the hydroxyapatite solution, $2.45 \mathrm{~g} \mathrm{CaCl}_{2}$ and $0.58 \mathrm{~g} \mathrm{NaCl}$ were added into $50 \mathrm{ml}$ of distilled water and mixed using a magnetic stirrer. Then, $1.150 \mathrm{~g} \mathrm{NaH} \mathrm{H}_{2} \mathrm{PO}_{4}$ (Sigma-Aldrich $99.5 \%$ trace metals basis) and $50 \mathrm{ml}$ of distilled water were separately mixed by a magnetic stirrer. Finally, the two solutions were mixed and stirred to obtain a hydroxyapatite solution.

To prepare $0.001 \mathrm{~mol} / \mathrm{L}$ Pt solution, $0.01 \mathrm{~g} \mathrm{~K}_{2} \mathrm{PtCl}_{4}$ powder was added to $25 \mathrm{ml}$ distilled water in an opaque flask.

Electrodeposition method was used to deposit the composite layer onto the substrate. $40 \mathrm{ml}$ hydroxyapatite, $40 \mathrm{ml}$ graphene oxide, and $25 \mathrm{ml} \mathrm{Pt}$ solutions were mixed and stirred for $30 \mathrm{~min}$. Then, the $\mathrm{pH}$ of the resulting solution was adjusted to 6 using $1 \mathrm{M} \mathrm{NaOH}$ in a water-bath at $80^{\circ} \mathrm{C}$. The electrodeposition (Potentiostat/Galvanostat/Impedance Analyzer, PARSTAT300) was performed in a standard threeelectrode cell using a chronoamperometry cycle in which pure zirconium substrate, a graphite rod, and a saturated calomel electrode (SCE) were the working electrode, the counter electrode, and the reference electrode, respectively (see Figure 1). The electrolyte was stirred smoothly at $80 \mathrm{rpm}$ during electrodeposition. The applied potential was kept at $-2 \mathrm{~V}$ for $7200 \mathrm{~s}$ (time per point was $2 \mathrm{~s}$ with total points of 3600). Finally, the electrodeposited samples were washed with deionized water and dried in an oven at $70^{\circ} \mathrm{C}$.

The electrochemical behavior of the uncoated, HA-, GO-, $\mathrm{HA} / \mathrm{GO}-$, and $\mathrm{HA} / \mathrm{GO} / \mathrm{Pt}$-coated samples were studied in a $\mathrm{CaCl}_{2}$ solution. A conventional three-electrode electrochemical cell with a platinum wire as a counter-electrode, a saturated calomel as a reference electrode, and the specimen, which served as the working electrode, were used. To let the open circuit potential (OCP) become stable, the samples were kept in the solution for $2 \mathrm{~h}$ before the electrochemical corrosion test. Potentiodynamic polarization tests were carried out, starting at $-250 \mathrm{mV}$ with reference to the OCP at a sweep rate of $0.5 \mathrm{mV}-1$ to a final current density of $0.1 \mathrm{mAcm}^{-2}$. Electrochemical impedance spectroscopy (EIS) was conducted at the OCP with an AC amplitude of $10 \mathrm{mV}$ over the frequency range of 10,000-0.01 Hz.

For the biocompatibility tests, to visualize the viable cells, the cell line MDA-MB-231, comprising a constitutively active GFP expression system, was used. Dulbecco's modified Eagle's medium (DMEM) with $1 \%$ pen strep (PS) antibiotic and $10 \%$ fetal bovine serum (FBS) was used for cell culture process in T-25 culture flasks using. Detailed info can be found in the study performed by Zalnezhad et al. [19].

The wear resistance tests of the coated samples were performed using a reciprocating ball-on-disc wear test machine. A $6 \mathrm{~mm}$ stainless steel ball was used for wear test at ambient temperature. In this experiment, the sliding speed and the track diameter were $1 \mathrm{~cm} / \mathrm{s}$ and $5 \mathrm{~mm}$, respectively. A $4 \mathrm{~N}$ normal load was applied in this work (see Figure 2). Five 


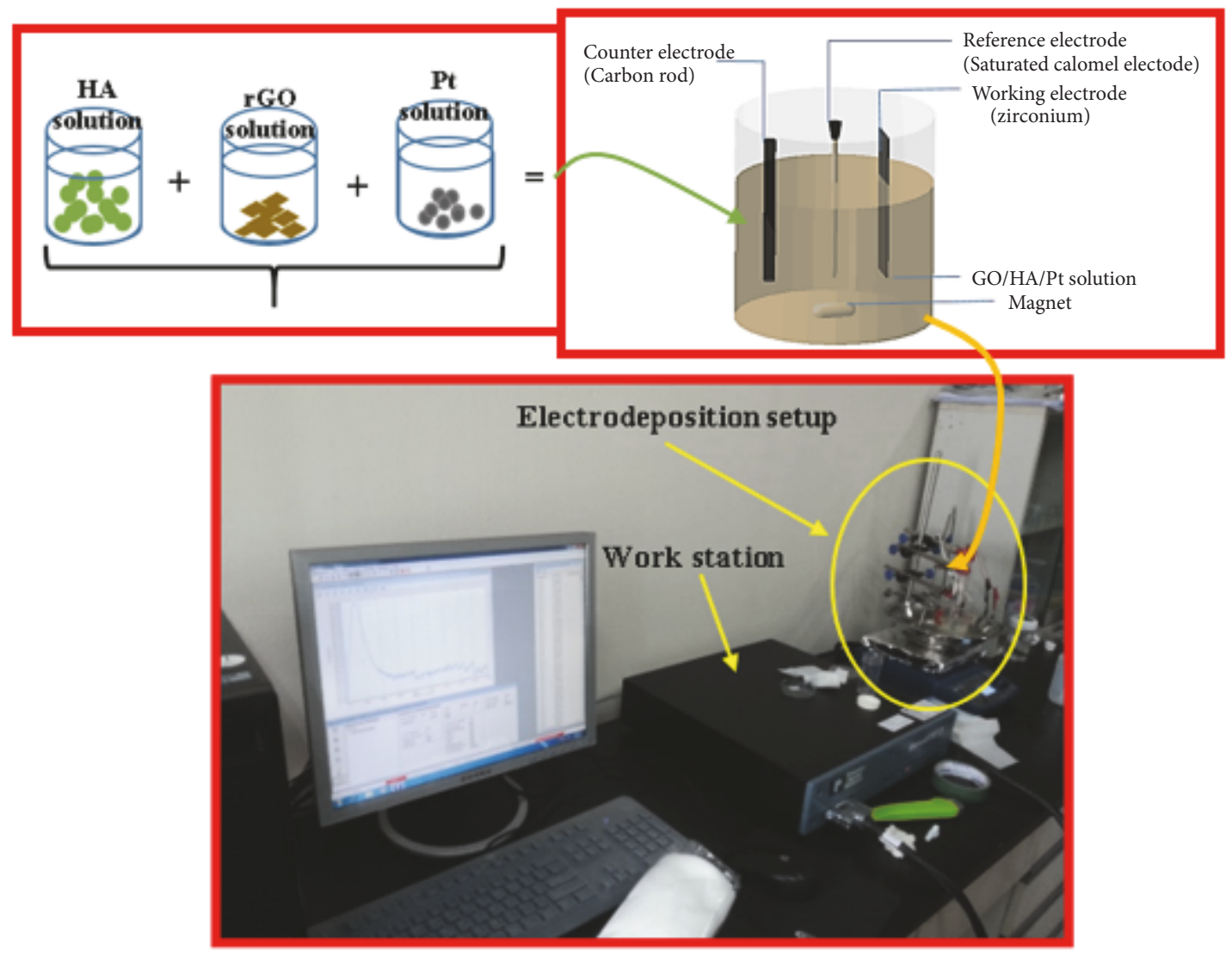

FIGURE 1: Experimental setup for electrodeposition.

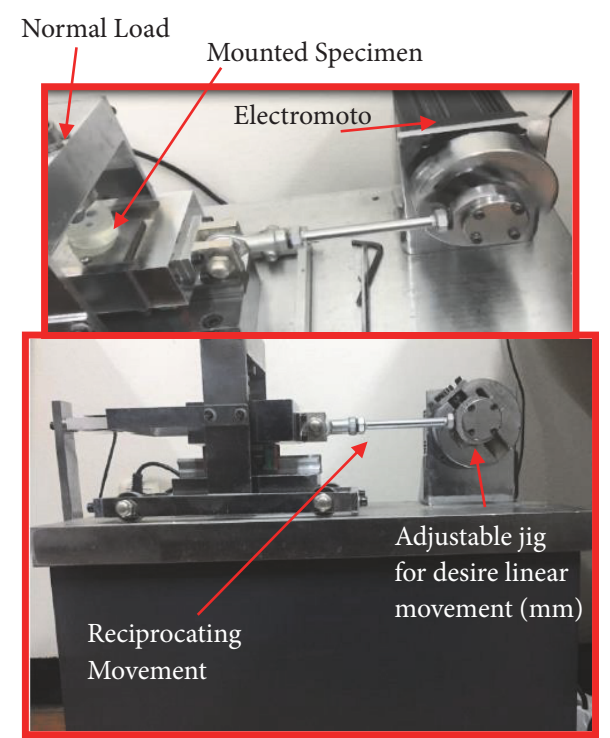

FIGURE 2: Reciprocating wear test setup.

experiments were carried out for each sample and friction coefficients of thin film deposited sample were recorded.

Furthermore, the morphology and structure of the deposited layer were characterized using FESEM (FEI, USA).
FT-IR tests were performed utilizing Nicolet iS50 FT-IR spectrometer in which the spectral resolution and the scan range were $0.5 \mathrm{~cm}^{-1}$ and $450-4000 \mathrm{~cm}^{-1}$, respectively. XRD (Smart Lab, Rigaku) peak intensity was measured with the scan-step of $2 \theta=20-80$, and a 0.02 step width in which the exposure time was $50 \mathrm{~s}$ per step. TEM was utilized to study the elemental composition and the morphology of the coatings (JEM-2010 TEM (JEOL, Japan).

To evaluate the influence of heat treatment on morphology and properties of coated substrates, a tube furnace equipped with Ar gas was used for the heating process of $\mathrm{HA} / \mathrm{GO} / \mathrm{Pt}$ coated samples at different temperatures including $200,300,400$, and $600^{\circ} \mathrm{C}$. The vacuum pressure and the Ar gas flow rate were $1.0 \times 10^{-3}$ torr and $200 \mathrm{sccm}$, respectively. The heating rate of $5^{\circ} \mathrm{C} \mathrm{min}^{-1}$ was selected until the desired temperature was achieved for $1.5 \mathrm{hr}$. Finally, the heated specimens were left at room temperature to cool naturally (see Figure 3).

\section{Results and Discussion}

3.1. Reaction Mechanism of Electrodeposition. Figure 4 shows the variation of the current with time during the coating process. It can be seen from the figure that the electrolyte within the active material began to react electrochemically within 2 minutes. The second minute to the fourth minute 


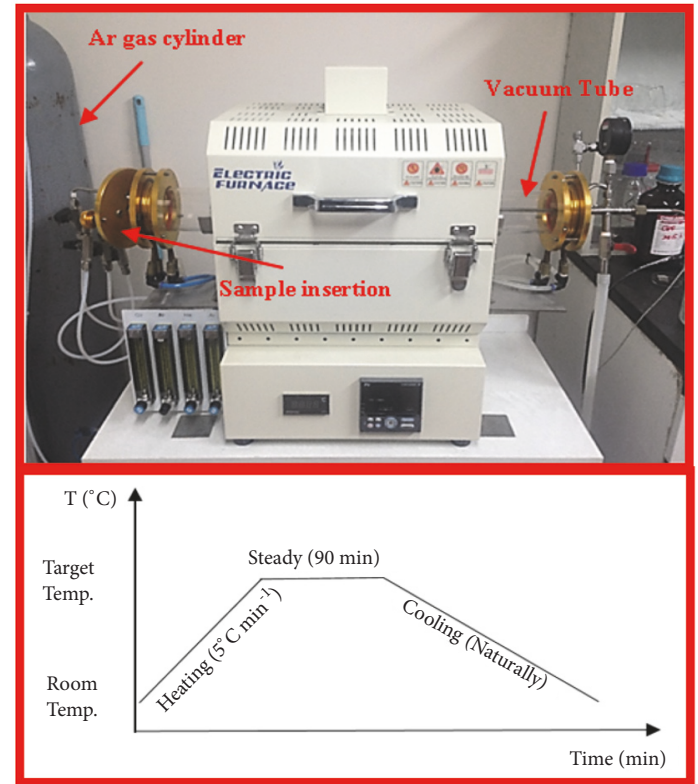

FIgURE 3: Tube furnace along with the heating and cooling graph.

the current density is slightly reduced, which indicates that the nucleation mechanism of the particles on the zirconium surface, this process is controlled by electron transfer. Note that the current density was reduced from 4 minutes to 10 minutes, which means that the deposited particles are coated on the zirconium surface by mass transfer and electron transfer processes. After 10 minutes to 30 minutes, due to the well transportation process, the current density tends to be stable. After 30 minutes, a large number of bubbles were observed on the zirconium surface, which is due to the hydrogen ions in the solution. Hydrogen spills in the electrodeposition synthesis which would affect the adhesion of the coating and the substrate and it would cause the coating to be uneven. Therefore, in order to synthesize an excellent coating which is not disturbed by hydrogen on the zirconium surface, the deposition time should be selected as 10 to 30 minutes. The electrodeposition time was 18 minutes in our investigation.

3.2. Structural and Morphological Analysis. XRD patterns for $\mathrm{HA}, \mathrm{HA} / \mathrm{GO}$, and $\mathrm{HA} / \mathrm{GO} / \mathrm{Pt}$ composite coatings are presented in Figure 5. The XRD diffraction peaks of the three samples can be found at (002), (211), (103), (401), and (213) that represents the typical structure of hydroxyapatite (JCPDS 09-0432). The diffraction peaks of (111), (220), and (200) appearing in the HA/GO/Pt sample indicate that the $\mathrm{HA} / \mathrm{GO} / \mathrm{Pt}$ composite was successfully synthesized (JCPDS 04-0802). In addition, the diffraction peaks of HA decreased after adding the $\mathrm{GO}$ and $\mathrm{GO} / \mathrm{Pt}$. The three most intensive peaks of (300), (103), and (401) between $30^{\circ}$ and $45^{\circ}(2 \theta)$ in a standard diffraction curve are not obvious which are possibly caused by low crystallinity or nanometer scale distribution. It is clear that the crystal size of hydroxyapatite is small from the sharp diffraction peaks $[20,21]$.
The characteristic absorption bands and corresponding wave numbers of $\mathrm{GO}, \mathrm{HA} / \mathrm{GO}$, and $\mathrm{HA} / \mathrm{GO} / \mathrm{Pt}$ coatings are indicated using FT-IR shown in Figure 6. The mutual absorbance bands at approximately $3285 \mathrm{~cm}^{-1}$ are assigned to the hydroxyl group $\left(\mathrm{OH}^{-}\right)$stretching. The position of the characteristic bands at $1018.42,981.17$, and $560.48 \mathrm{~cm}^{-1}$ in the FT-IR is attributed to the stretching and bending of phosphate [22]. The characteristic band at $601.55 \mathrm{~cm}^{-1}$ is attributed to the vibrational mode of the $\mathrm{OH}^{-}$group in the HA structure $[23,24]$. The band at $871.42 \mathrm{~cm}^{-1}$ is assigned to the $\mathrm{P}-(\mathrm{OH})$ stretching vibration in the $\mathrm{HPO}_{4}$ 2- phosphate group $[25,26]$. The bands at $1653 \mathrm{~cm}^{-1}$ and $1456 \mathrm{~cm}^{-1}$ are assigned to the stretching vibrations of the carboxyl group (COOH-) on the edge of the basal planes or the conjugated carbonyl groups $(\mathrm{C}=\mathrm{O})$ and the $\mathrm{sp} 2$ hybridized $\mathrm{C}=\mathrm{C}$ vibration stretching, respectively [27]. The absorption bands of the methylene groups $\left(\mathrm{CH}_{2}\right)$, which are inherent in the $\mathrm{GO}$, are present at approximately $2959 \mathrm{~cm}^{-1}$ and $2928 \mathrm{~cm}^{-1}$. The peak at $1425 \mathrm{~cm}^{-1}$ is attributed to the deformation of the $\mathrm{O}-\mathrm{H}$ [28]. In contrast, the peaks at $1750 \mathrm{~cm}^{-1}$ and $1425 \mathrm{~m}^{-1}$ in the FTIR spectrum of the HA/GO composite are no longer visible, which points to the reduction of GO.

Structural analysis and surface morphology of electrodeposited thin film HA/GO/Pt nanocomposite over zirconium substrate were performed using SEM and TEM. Figures $7(\mathrm{a})-7$ (f) show SEM micrographs of HA/GO/Pt coating at different magnifications. The surface of the pure zirconium substrate is covered by hydroxyapatite particles, Pt nanowalls, and graphene nanosheets all over the substrate. As can be seen, the coating is porous. An SEM micrograph of the composite coating (Figure 7(a)) shows the characteristic morphology for HA agglomerates with different sizes. The SEM micrograph of the HA/GO/Pt composite coating (Figure $7(\mathrm{c})$ ) shows HA particles and nanowalls wrapped by reduced graphene oxide nanosheets. Incorporation of graphene changes the morphology of the composite coating significantly. Figure $7(\mathrm{e})$ shows wave-like graphene sheets, well dispersed in a broccoli-looking $\mathrm{HA} / \mathrm{Pt}$. In addition, in $\mathrm{HA} / \mathrm{GO} / \mathrm{Pt}$ a distribution of HA particles in the Pt/graphene matrix is observed. HA and graphene are connected by Van der Waals bonding [29]. Therefore, HA crystals nucleation is perhaps created on either the cross-section of graphene multi-sheets or the graphene wall, followed by succeeding crystal growth perpendicular or along the graphene sheet's surface. Figure 7(g) and h show the TEM at different magnifications and Figure 7(i) shows the EDS elemental analysis of $\mathrm{HA} / \mathrm{GO} / \mathrm{Pt}$ composite. As can be seen the composite coating consists of $\mathrm{Ca}, \mathrm{P}, \mathrm{Pt}, \mathrm{O}_{2}$, and C elements in EDX indicating the presence and contribution of $\mathrm{Pt}(\sim 33.38 \mathrm{wt} . \%)$, HA nanowalls ( 32.96 wt. $\%)$, and graphene oxide nanosheets ( 20.28 wt.\%) in the HA/GO/Pt composite thin film.

Figure 8 shows a cross-sectional FESEM-EDX micrograph of an $\mathrm{HA} / \mathrm{GO} / \mathrm{Pt}$ coating on the zirconium substrate in which the thickness of the composite thin layer is found to be around $1.1 \mu \mathrm{m}$. The deposited layer was uniform in structure and there were no 3D microscopic bulk defects. In the EDS analysis, line scanning method from the cross-section was carried out to detect the elemental composition the coating to 


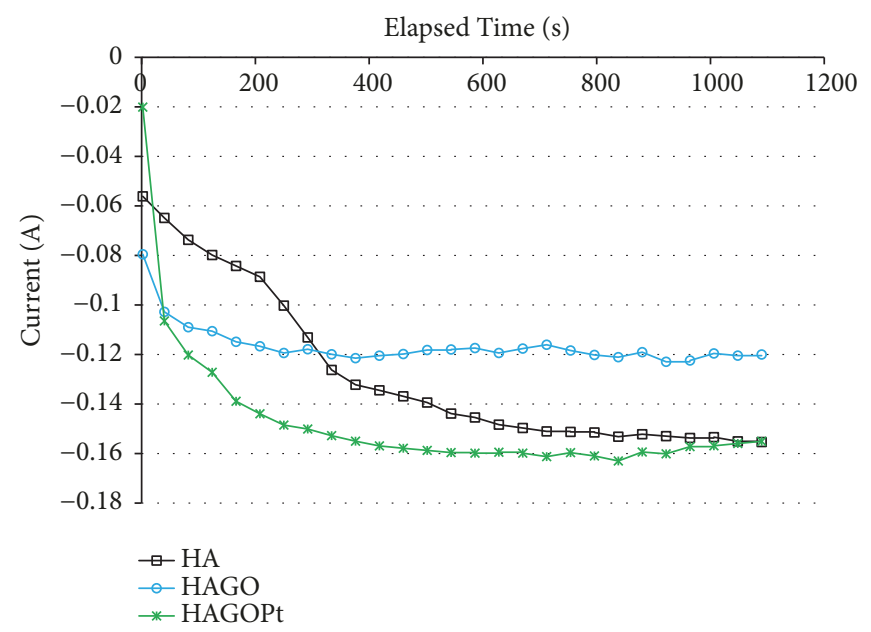

FIGURE 4: Chronoamperometry plot of electrodeposition process of different coatings.

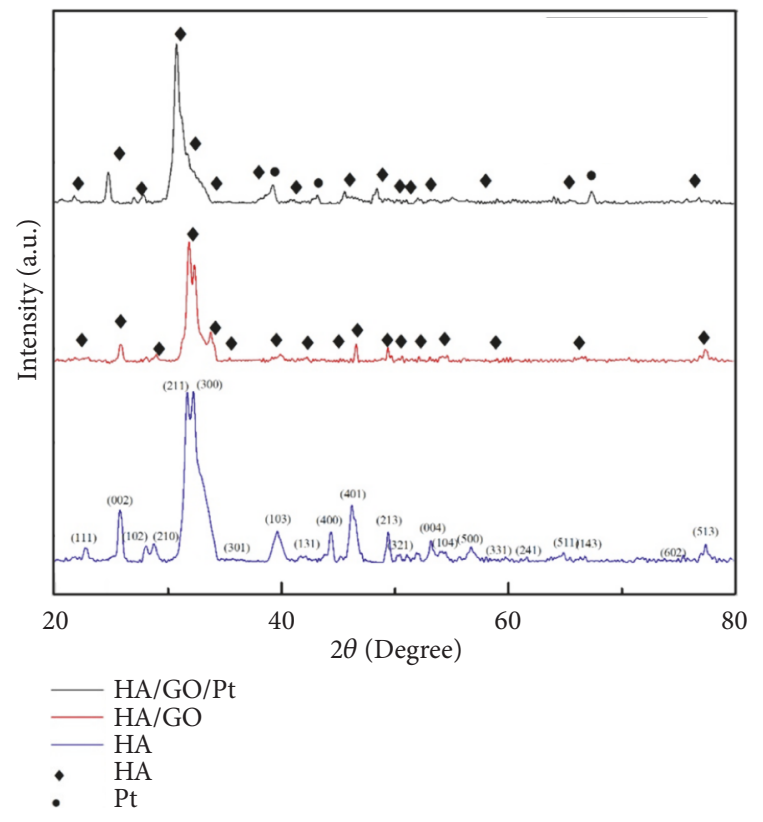

Figure 5: X-ray diffraction patterns for the synthesized HA, $\mathrm{HA} / \mathrm{GO}$, and $\mathrm{HA} / \mathrm{GO} / \mathrm{Pt}$.

confirm the creation of $\mathrm{HA} / \mathrm{GO} / \mathrm{Pt}$ thin film on the zirconium substrate. From the EDS line scanning, elements such as C, $\mathrm{O}, \mathrm{Pt}, \mathrm{P}$, and $\mathrm{Ca}$ are detected over the substrate, indicating that they are incorporated into the surface structure during electrodeposition. It further confirmed the formation of $\mathrm{HA} / \mathrm{GO} / \mathrm{Pt}$ composite coatings on the zirconium substrates.

3.3. Biocompatibility Tests. Figures 9(a)-9(d) present the biocompatibility tests of uncoated and HA-, HA/GO-, and $\mathrm{HA} / \mathrm{GO} / \mathrm{Pt}$-coated zirconium. In looking at the biocompatibility, the uncoated zirconium surface was not capable of providing extensive attachment and growth of the adenocarcinoma cells. In stark distinction, the HA and HA/GO coating surfaces allowed cell attachment and proliferation as was observed by the bright fluorescent signal from the green fluorescent protein (GFP) produced within the viable MDAMB-231 cells. In addition, the cell spreading on the surface was indicative of a characteristic epithelial morphology suggesting strong adhesion and biocompatibility of the surface. The biocompatibility of the HA/GO/Pt surface similarly permitted cell spreading and proliferation. From Figures 6(a)-6(d), it can be realized that the cell proliferation and distribution on the HA/GO/Pt coating decrease compared to HA and HA/GO coatings, but it is better than bare Zr. It can be concluded that Pt may have no a significant effect on biocompatibility and cell proliferation in $\mathrm{HA} / \mathrm{GO} / \mathrm{Pt}$ composite. In our previous study [30], we found that the bare stainless steel 304 surface had no significant cells growth and attachment. But, SST 304 surface deposited by HA allowed cell proliferation and attachment. But a better growth in biocompatibility was seen for $\mathrm{HA} / \mathrm{rGO}$ thin layer. Furthermore, the $\mathrm{HA} / \mathrm{rGO} / \mathrm{Pd}$ deposited layer onto stainless steel 304 surface allowed even more enhanced cell proliferation and spreading, concluding that Pd may have a better and more significant influence on the biocompatibility of the composite compared to the Pt element.

3.4. Electrochemical Measurements in $\mathrm{CaCl}_{2}$ Solution. In order to evaluate the corrosion stability in physiological media, EIS and PDS measurements in $\mathrm{CaCl}_{2}$ solution were performed.

3.4.1. Electrochemical Impedance Spectroscopy. Nyquist plots of pure zirconium, zirconium coated with HA, HA/GO, and $\mathrm{HA} / \mathrm{GO} / \mathrm{Pt}$ coatings after different immersion times in $\mathrm{CaCl}_{2}$ solution are shown in Figures 10(a)-10(e), respectively. In general, the high-frequency range of the Nyquist plots is attributed to the coating, while the low frequency range describes electrochemical processes on the metal surface beneath the coating. The EEC contains the coating pore resistance $R_{c}$, the electrolyte resistance $R_{s}$, and constant phase elements $\mathrm{CPE}_{\mathrm{ox}}$ and $\mathrm{CPE}_{\mathrm{c}}$ that represent all of the 


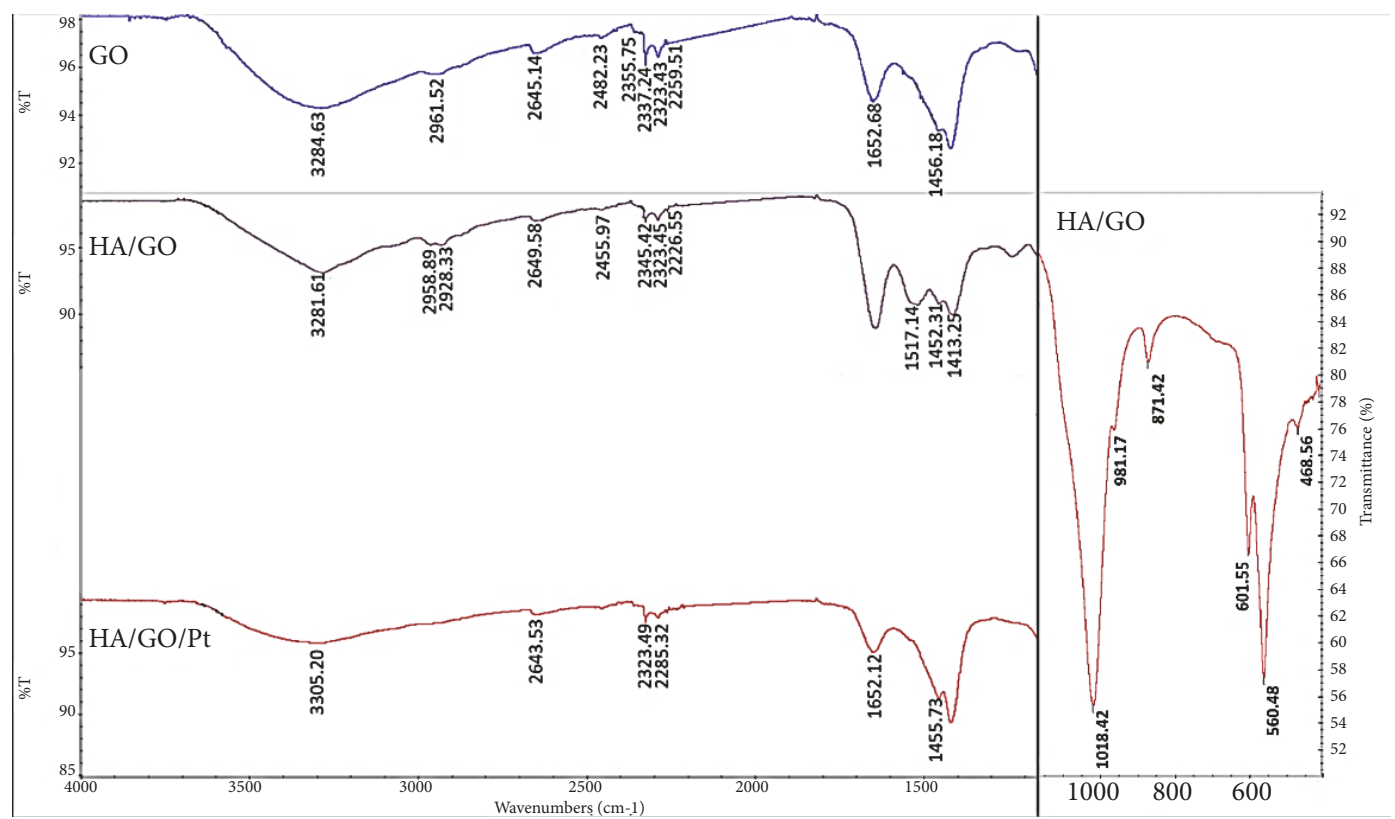

FIGURE 6: FT-IR spectra of GO, HA/GO and HA/GO/Pt coatings on zirconium.

TABLE 1: Current density, $\mathrm{I}_{\text {corr }}$, and corrosion potential, $\mathrm{E}_{\text {corr }}$, obtained from PDS measurements for an uncoated substrate and HA, HA/GO, and $\mathrm{HA} / \mathrm{GO} / \mathrm{Pt}$ coatings on zirconium after 7 days.

\begin{tabular}{|c|c|c|c|c|}
\hline Time/day & Uncoated substrate & HA coating & HA/GO coating & HA/GO/Pt coating \\
\hline \multicolumn{5}{|l|}{$\mathrm{I}_{\text {corr }} / \mathrm{nA}$} \\
\hline 7 & 279.602 & 72.1 & 50.044 & 27.227 \\
\hline \multicolumn{5}{|l|}{$\mathrm{E}_{\text {corr }} / \mathrm{mV}$} \\
\hline 7 & -21.699 & 164.574 & 267.02 & 499.325 \\
\hline
\end{tabular}

frequency-dependent electrochemical phenomena, including the capacitance of the passive oxide layer on the $\mathrm{Zr}$ surface beneath the coating $\mathrm{C}_{\mathrm{ox}}$ and the coating capacitance $\mathrm{C}_{\mathrm{c}}$ [31].

Potentiodynamic sweep measurements in $\mathrm{CaCl}_{2}$ was performed to get information about the corrosive properties of the uncoated, HA-, HA/GO, and HA/GO/Pt-coated substrates, since the corrosion rate is proportional to the current density. Potentiodynamic polarization curves of the uncoated, HA-, HA/GO, and $\mathrm{HA} / \mathrm{GO} / \mathrm{Pt}$-coated substrates after 7 days in $\mathrm{CaCl}_{2}$ solution are plotted in Figure 10. The corrosion current density $\mathrm{I}_{\text {corr }}$ and corrosion potential $\mathrm{E}_{\text {corr }}$ were evaluated according to Tafel extrapolation and are listed in Table 1. The $\mathrm{E}_{\text {corr }}$ of pure zirconium $(-21.699 \mathrm{mV})$ and HA coating $(164.574 \mathrm{mV})$ is less positive than the $\mathrm{E}_{\text {corr }}$ of $\mathrm{HA} / \mathrm{GO}(267.02 \mathrm{mV})$ and HA/GO/Pt (499.325 mV). However, $\mathrm{I}_{\text {corr }}$ of bare pure zirconium, HA, HA/GO, and $\mathrm{HA} / \mathrm{GO} / \mathrm{Pt}$ is $279.602,72.1,50.044$, and $27.227 \mathrm{nA}$, respectively. $\mathrm{I}_{\text {corr }}$ of $\mathrm{HA} / \mathrm{GO}$ and $\mathrm{HA} / \mathrm{GO} / \mathrm{Pt}$ is lower than $\mathrm{I}_{\text {corr }}$ of $\mathrm{HA}$ and uncoated substrate, implying that graphene and $\mathrm{Pt}$ improve the corrosion resistance of the $\mathrm{Zr}$ substrate in $\mathrm{CaCl}_{2}$ solution as a consequence of the bioactivity of the formed apatite layer on HA/GO- and HA/GO/Pt-coated surface.

The results of polarization measurements are in accordance with the impedance spectroscopy results, indicating that the $\mathrm{HA} / \mathrm{GO}$ and $\mathrm{HA} / \mathrm{GO} / \mathrm{Pt}$ coatings have better corrosion resistance and the lowest corrosion rate due to the thick biomimetic apatite layer on their surfaces. Therefore, the use of graphene-based HA/GO and HA/GO/Pt composite coatings may improve the corrosion resistance, decrease metal ion release. Fadol et al. evaluated the influence of $\mathrm{HA} / \mathrm{rGO} / \mathrm{Pd}$ on the corrosion behavior of SST304. They found that the uncoated SST 304 had $\mathrm{E}_{\text {corr }}=0.13 \mathrm{~V}$, with a quite high current density, though the EIS test evidently showed that the electrodeposited SST 304 results in very small $I_{\text {corr }}$ compared to the bare substrate. The lower $I_{\text {corr }}$ was attributed to the contribution of graphene oxide nanosheets into the solutions that enhanced the rate of the electrodeposition and resulted in thicker film. Owing to the impermeable to molecules and chemical inertness of graphene, it plays a significant role as every corrosion resistance layer on a metallic material by performing like a natural diffusion obstacle. Inclusion of palladium in $\mathrm{HA} / \mathrm{rGO}$ inhibited the corrosion process of the sample, probably because of the existence of palladium at grain boundaries that helps the corrosion resistance of the substrates [30]. A comparative investigation on the effect of $\mathrm{HA} / \mathrm{GO} / \mathrm{Pd}$ and $\mathrm{HA} / \mathrm{GO} / \mathrm{Pt}$ thin film layers shows that although, in the previous study, the HA/GO/Pd composite layer improved the corrosion resistance of SST304 significantly, HA/GO/Pt presents a better corrosion behavior for pure zirconium substrate. This may be due to the presence 


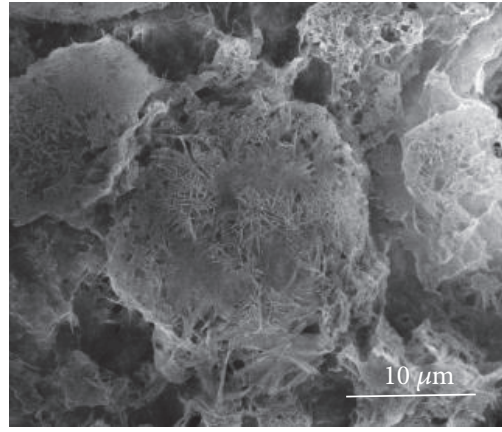

(a)

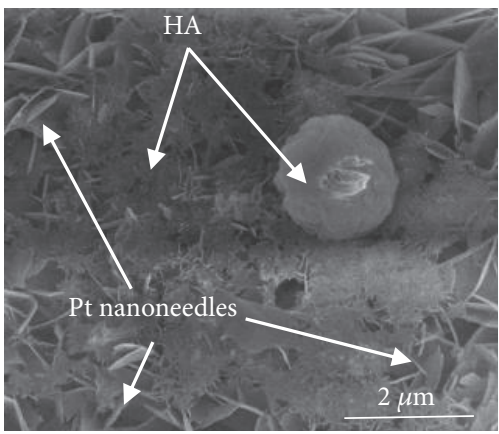

(d)

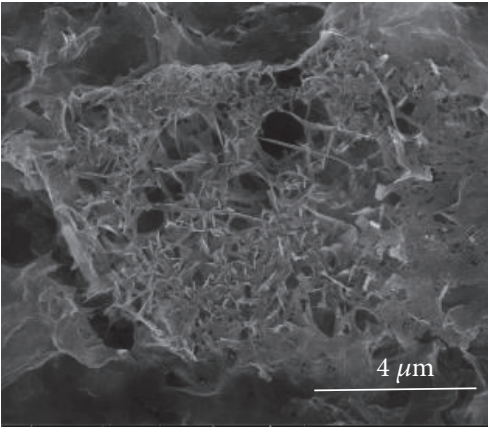

(b)

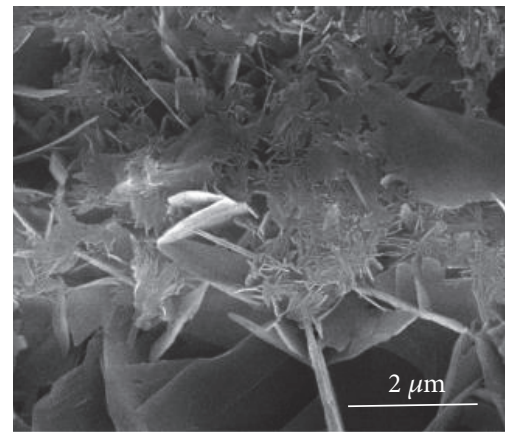

(e)

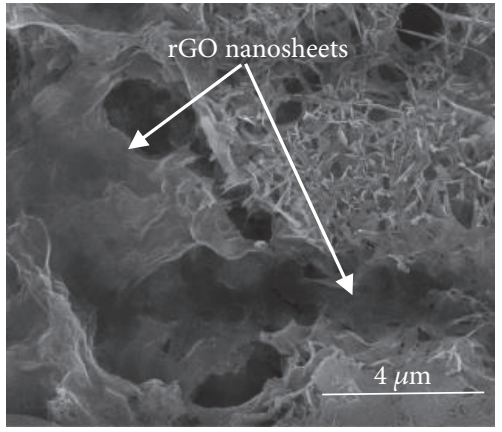

(c)

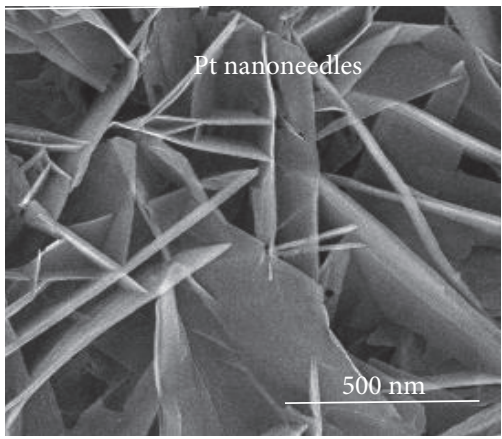

(f)

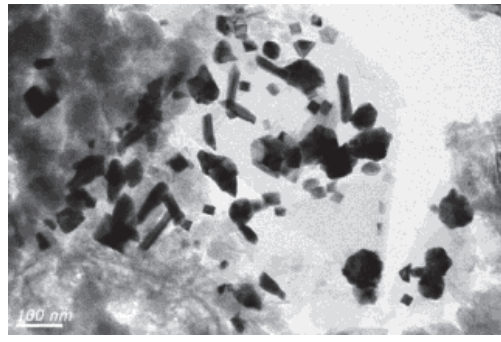

(g)

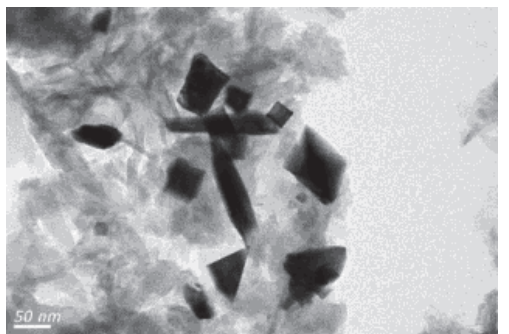

(h)

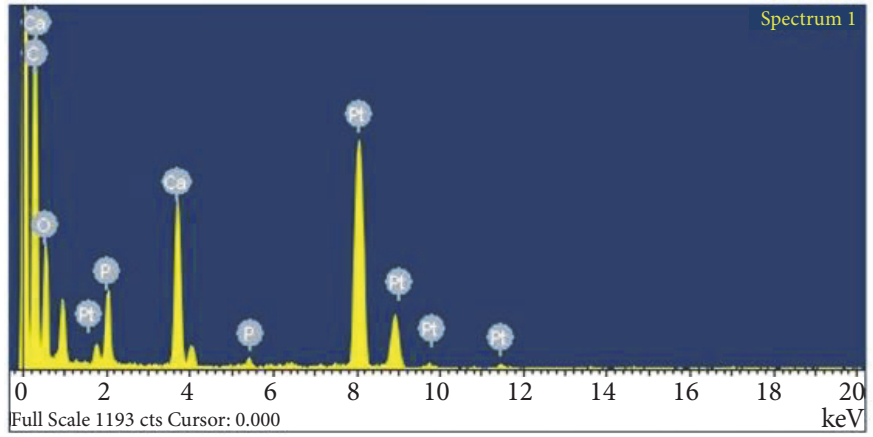

(i)

FIgURE 7: FESEM images-top views (a-f), TEM ( $\mathrm{g}$ and $\mathrm{h}$ ), and EDS (i) of HA/GO/Pt.

and better contribution of the Pt element as a barrier at grain boundaries in $\mathrm{HA} / \mathrm{GO} / \mathrm{Pt}$ composite layer.

3.4.2. Corrosion Behavior and Surface Morphology of the Thermal Treated HA/GO/Pt Coated Zirconium. Figure 11 shows the polarization curves of $\mathrm{HA} / \mathrm{GO} / \mathrm{Pt}$ nanocomposites heat treated at 200, 300, 400, and $600^{\circ} \mathrm{C}$. Table 2 summarizes their respective $\mathrm{E}_{\text {corr }}$ and $\mathrm{I}_{\text {corr }}$. The corrosion potential, $\mathrm{E}_{\text {corr }}$, of $\mathrm{HA} / \mathrm{GO} / \mathrm{Pt}$ coated samples annealed at 200, 300, 400, and $600^{\circ} \mathrm{C}$ is $1.731,232.858,379.096$, and $309.423 \mathrm{mV}$, respectively. The results show that $\mathrm{HA} / \mathrm{GO} / \mathrm{Pt}$ coated substrate annealed at different temperatures has $\mathrm{E}_{\text {corr }}$ lower than $\mathrm{E}_{\text {corr }}$ of the untreated $\mathrm{HA} / \mathrm{GO} / \mathrm{Pt}$ coating, indicating that the heat 


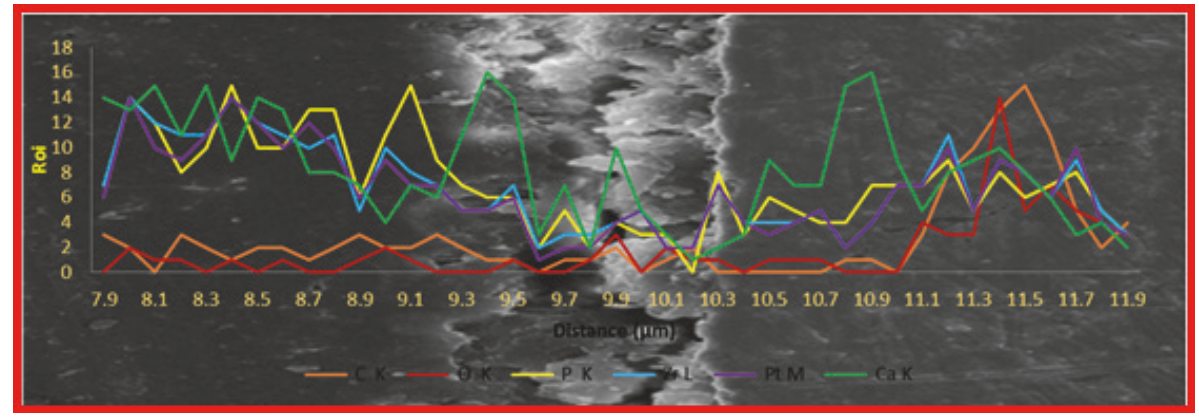

FIGURE 8: Cross-sectional FESEM micrographs and elemental profile plot of HA/GO/Pt coating.

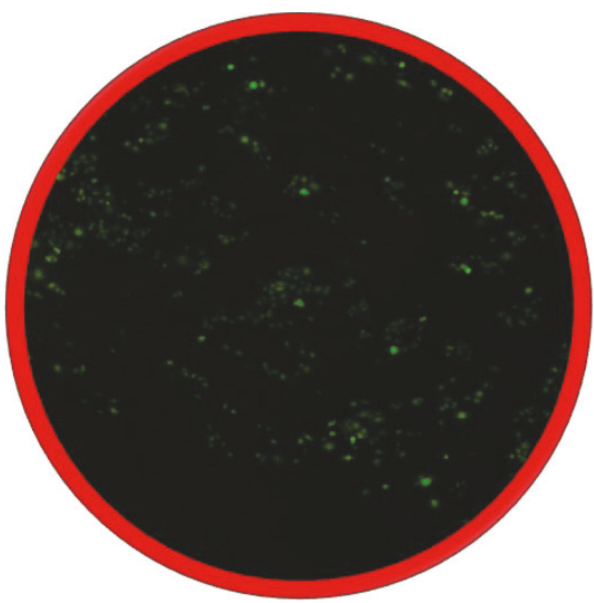

(a)

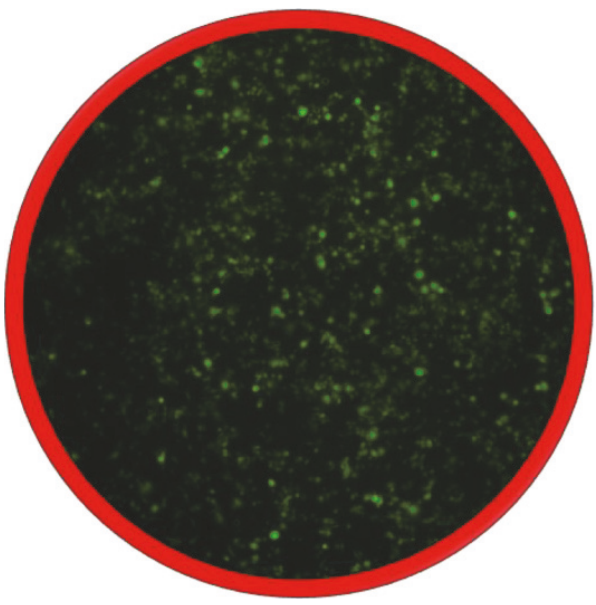

(c)

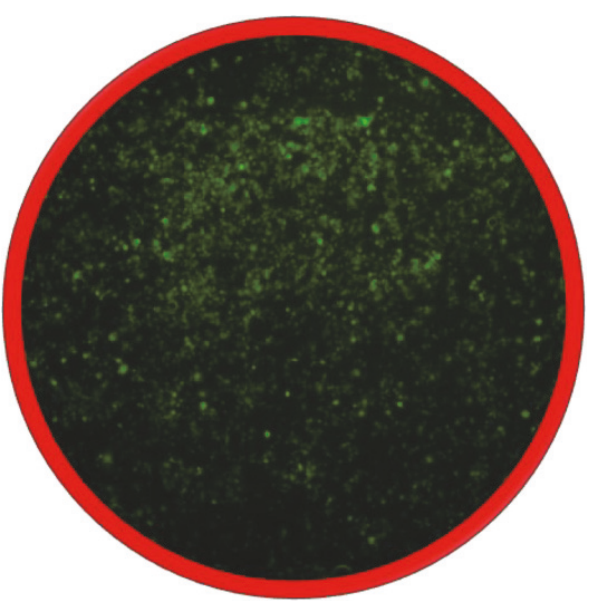

(b)

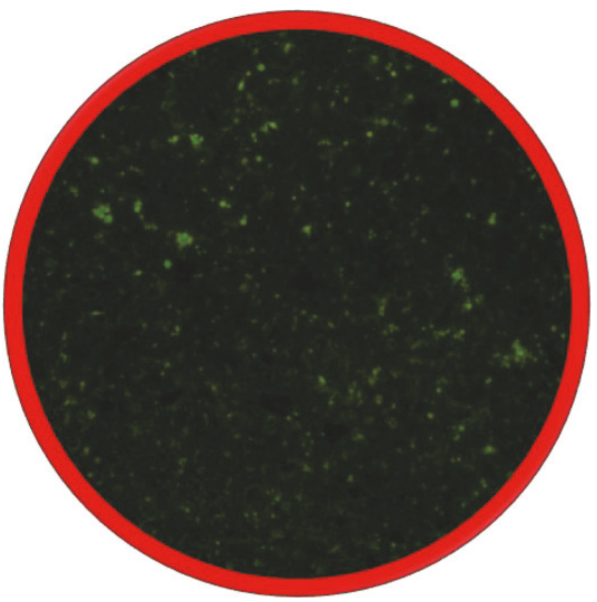

(d)

FIGURE 9: Biocompatibility of the (a) uncoated and (b) HA, (c) HA/GO, and (d) HA/GO/Pt coated substrate using the human cell line MDAMB-231 possessing a green fluorescent protein as a reporter for living cells.

TABLE 2: Corrosion current density, Icorr, and corrosion potential, Ecorr, obtained from PDS measurements for corrosion behaviors of the thermal treated $\mathrm{HA} / \mathrm{GO} / \mathrm{Pt}$ coated zirconium.

\begin{tabular}{lcccc}
\hline Time/day & HT200 & HT300 & HT400 & HT600 \\
\hline $\mathrm{I}_{\text {corr }} / \mathrm{nA}$ & 16.269 & & & 1.521 \\
2 & & 17.035 & & 14.15 \\
$\mathrm{E}_{\text {corr }} / \mathrm{mV}$ & 1.731 & 232.858 & 379.096 & 309.423 \\
2 & & & & \\
\hline
\end{tabular}




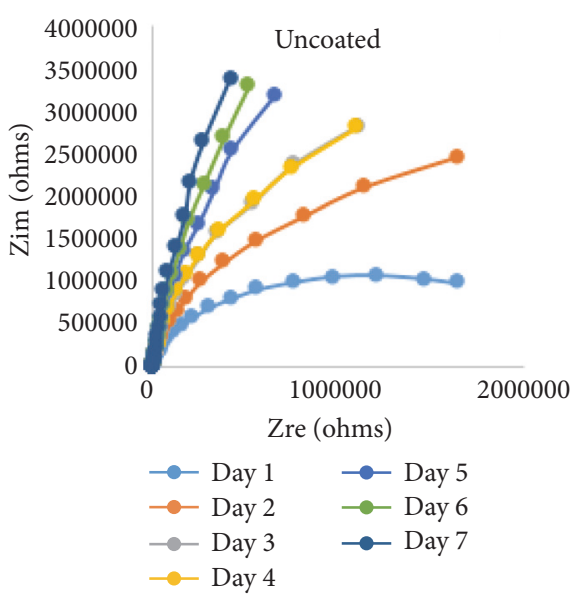

(a)

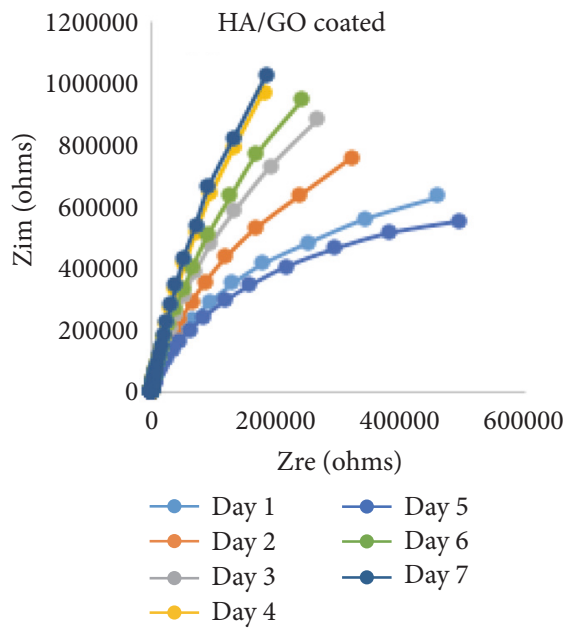

(c)

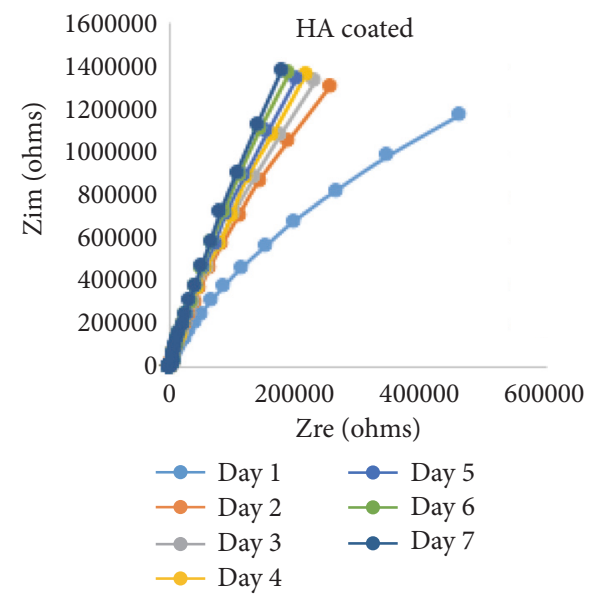

(b)

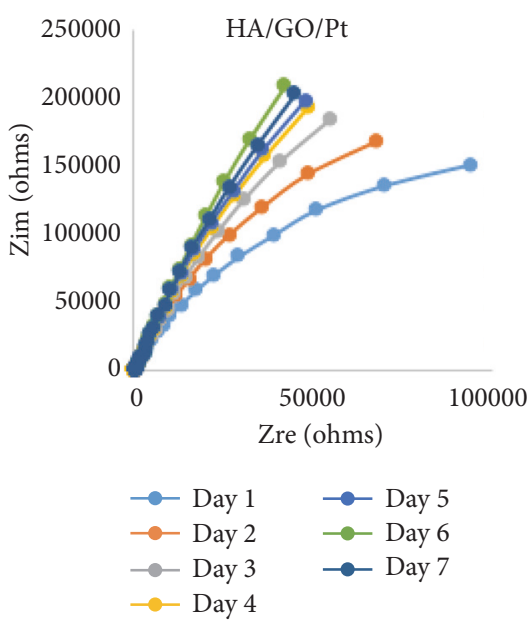

(d)

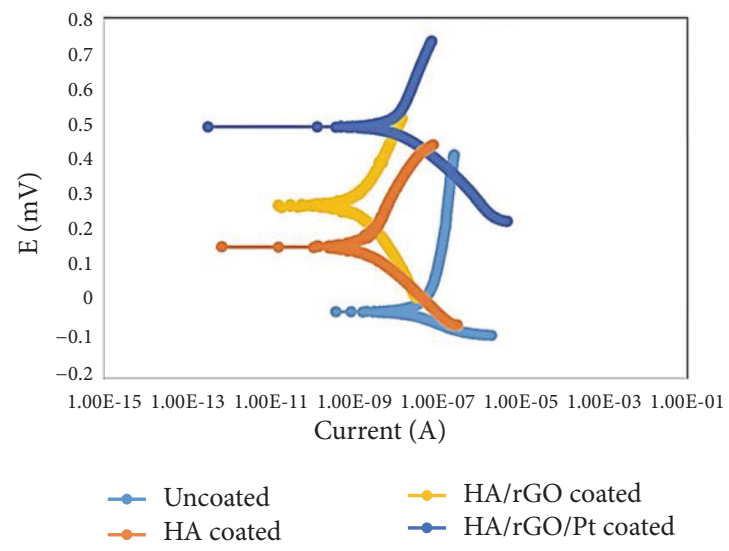

(e)

Figure 10: EIS spectra of (a) pure zirconium, (b) HA, (c) HA/GO, and (d) HA/GO/Pt coatings on zirconium substrate during prolonged time (7 days). (e) Potentiodynamic polarization curves of uncoated and coated zirconium after 7 in $\mathrm{CaCl}_{2}$ solution.

treatment has a significant effect on corrosion potential of the composite coating. The current densities of the HA/GO/Pt coatings heat treated at 200 and $300^{\circ} \mathrm{C}$ were $16.269 \mathrm{nA}$ and $17.035 \mathrm{nA}$, which were also lower than the current density of the untreated HA/GO/Pt coatings (27.227 nA). This indicates that the corrosion resistance of $\mathrm{HA} / \mathrm{GO} / \mathrm{Pt}$ coatings is enhanced by heat treatment. The higher corrosion potential $\left(\mathrm{E}_{\text {corr }}\right)$ and the lower corrosion current density $\left(\mathrm{I}_{\text {corr }}\right)$ indicate that the material has better corrosion resistance. For the heat treatment temperature of $400^{\circ} \mathrm{C}\left(\mathrm{E}_{\mathrm{corr}} 379.096 \mathrm{mV} \mathrm{I}\right.$ corr 


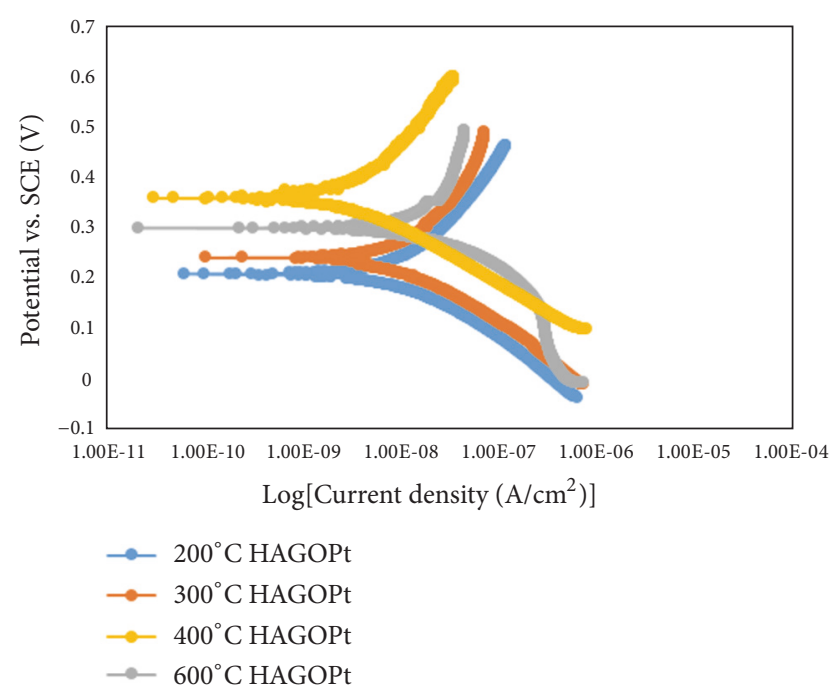

FIgURE 11: The corrosion behaviors of the thermal treated $\mathrm{HA} / \mathrm{GO} / \mathrm{Pt}$ coated zirconium.

$1.521 \mathrm{nA}$ ), it achieved the best corrosion resistance. As can be seen, with increasing the annealing temperature from 200 to $400^{\circ} \mathrm{C} \mathrm{I}_{\text {corr }}$ decrease showing a better corrosion resistance and that can be caused by the diffusion of coatings into the substrate and integration of the composite materials during the heat treatment process. Further increasing in temperature to $600^{\circ} \mathrm{C}$ led to increasing in $\mathrm{I}_{\text {corr }}=14.15$ indicating a decrease in corrosion resistance which can be due to cracks in the coatings or coating detachment because of different modulus of elasticity between the coating and the substrate. In the previous study by Fadol et al. [28] HA/GO/Pd was heated at versatile temperatures $\left(200-600^{\circ} \mathrm{C}\right)$ and $200^{\circ} \mathrm{C}$ heating of $\mathrm{HA} / \mathrm{rGO} / \mathrm{Pd}$ showed better corrosion potential and current density compared to the other heat treated HA/GO/Pd. Compared with the nonannealed and other annealed samples, the $\mathrm{E}_{\text {corr }}$ for $200^{\circ} \mathrm{C}$ annealed $\mathrm{HA} / \mathrm{rGO} / \mathrm{Pd}$ was more positive and the plot had a tendency toward lower current density. This severe change in electrochemical behavior of the composite electrodeposited substrate may be due to the penetration of electrolyte into the defects of the thin layers caused at higher temperatures. This indicates that annealing of $\mathrm{HA} / \mathrm{rGO} / \mathrm{Pd}$ electrodeposited substrate at lower temperature has a better protective effect. Furthermore, heat treatment of HA/GO/Pt at $400^{\circ} \mathrm{C}$ shows a better corrosion behavior for pure zirconium substrate compared to $\mathrm{HA} / \mathrm{rGO} / \mathrm{Pd}$ coated SST304 annealed at $200^{\circ} \mathrm{C}$ (showed the best corrosion resistance).

Figures 12(a) and 12(b) present the surface of the nonannealed bare and $\mathrm{HA} / \mathrm{GO} / \mathrm{Pt}$ coated zirconium substrates immersed into the $\mathrm{CaCl}_{2}$ solution for 7 days. As can be seen, the corrosion spots of the coated samples are less than bare samples one. It indicates that the coating can effectively improve the corrosion resistance. To better investigate the influence of the low $\left(200^{\circ} \mathrm{C}\right)$ and high $\left(600^{\circ} \mathrm{C}\right)$ temperatures on morphologies of the thin film coated substrate before and after EIS tests, the SEM analysis conducted and the results are depicted in Figures 13(a)-13(d). As can be seen from Figure 13(c), increasing in the annealing temperature to $600^{\circ} \mathrm{C}$ led to the creation of cracks all over the coatings due to the difference in elastic moduli in coating materials and the substrate resulting in a decrease of corrosion resistance as the corrosion solution penetrated to the substrate through the cracks. It can be concluded that high annealing temperature such as $400^{\circ} \mathrm{C}$ may have a better influence on corrosion resistance of $\mathrm{HA} / \mathrm{GO} / \mathrm{Pt}$ composite.

Figure 14 shows the XRD patterns of annealed HA/GO/Pt deposited zirconium substrate before and after EIS tests. Hydroxyapatite peaks with high intensity at (002) and (211) crystal planes at $25.8^{\circ}$ and $32.0^{\circ}$ show perfect match with the hydroxyapatite pattern (PDF\#09-0432). Furthermore, the XRD analysis after soaking the coated samples in the corrosion medium for seven days shows the formation of the carbonated hydroxyapatite as the angle of crystal planes (002) and (211) shifted. The formation of the carbonated hydroxyapatite is favorable as it characterizes the mineral phase in human bone. The availability of the functional groups in the biomimetic synthetic serum can help the growth of the hydroxyapatite on the electrodeposited surface [32]. The hydroxyapatite surface charges negatively and thus attracts ions of $\mathrm{Ca}+2$ by the exposure of the phosphate and hydroxyl ions in hydroxyapatite to the biomimetic synthetic serum. Calcium phosphate precipitates due to the high calcium ions consumption. Simultaneously, hydroxyapatite dissolves, enhancing the phosphate and calcium concentrations in the synthetic solution, which results in hydroxyapatite precipitation. The reaction during calcium phosphate dissolution and precipitation in the biomimetic synthetic medium is reversible [33]. Because of the negative surface charge of graphene coming from $\mathrm{p}$ electrons proliferation in sp 2 hybrid orbitals, graphene can enhance the hydroxyapatite deposition rate by attracting ions of calcium [34].

3.5. Friction Coefficient and Wear Analysis. Figure 15 presents the COF and wear loss of bare substrate, HA/GO/Pt (before annealing), and heated $\mathrm{HA} / \mathrm{GO} / \mathrm{Pt}$ electrodeposited zirconium at different heating temperatures. It is clearly evident that $\mathrm{COF}$ of $\mathrm{HA} / \mathrm{GO} / \mathrm{Pt}$ deposited zirconium affects by annealing at different temperatures. Average COF of the bare substrate, $\mathrm{HA} / \mathrm{GO} / \mathrm{Pt}$ (before annealing), and annealed $\mathrm{HA} / \mathrm{GO} / \mathrm{Pt}$ coated substrates at $200,300,400$, and $600^{\circ} \mathrm{C}$ are $0.84,0.75,0.66,0.54,0.57$, and 0.59 , respectively. Definitely, the COF of electrodeposited zirconium heated at $300^{\circ} \mathrm{C}$ presents a significantly lower average COF compared to other specimens.

The wear rates of the pure substrate and $\mathrm{HA} / \mathrm{GO} / \mathrm{Pt}$ (before annealing) and heat treated $\mathrm{HA} / \mathrm{GO} / \mathrm{Pt}$ coated substrate at $200,300,400$, and $600^{\circ} \mathrm{C}$ are $3.45,3.12,2.23,2.02$, 2.68 , and $2.73 \mathrm{~mm}^{3} / \mathrm{m}$, respectively (see Figure $15(\mathrm{a})$ ). The zirconium substrate wear rate was higher than the composite coatings, signifying that composite coatings significantly improved the wear resistance of the $\mathrm{Zr}$ substrate. $\mathrm{HA} / \mathrm{GO} / \mathrm{Pt}$ annealed at $300^{\circ} \mathrm{C}$ shows to have a better wear resistance compared to the other samples.

The optical microscopic images of worn surface of $\mathrm{HA} / \mathrm{GO} / \mathrm{Pt}$ treated from 200 to $600^{\circ} \mathrm{C}$ under reciprocating movement with an applied normal load of $4 \mathrm{~N}$ are shown in 


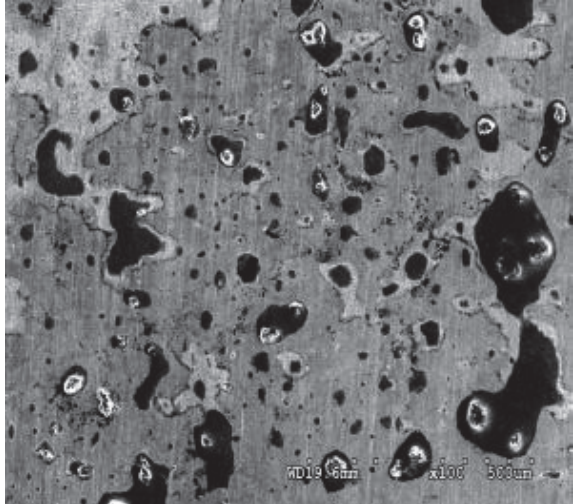

(a)

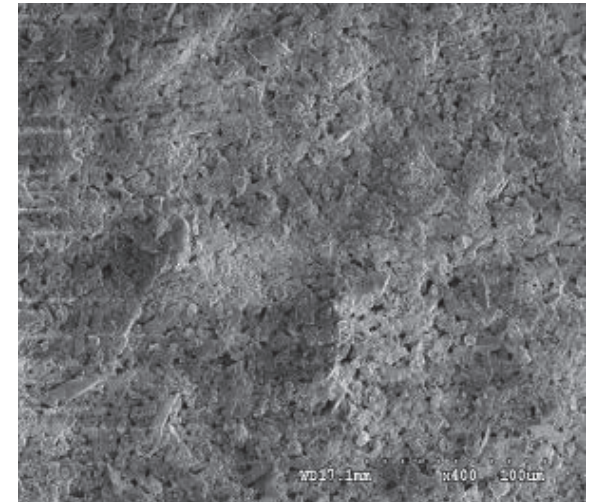

(b)

FIGURE 12: SEM micrographs of (a) bare and (b) HA/GO/Pt coated sample before and after corrosion test.

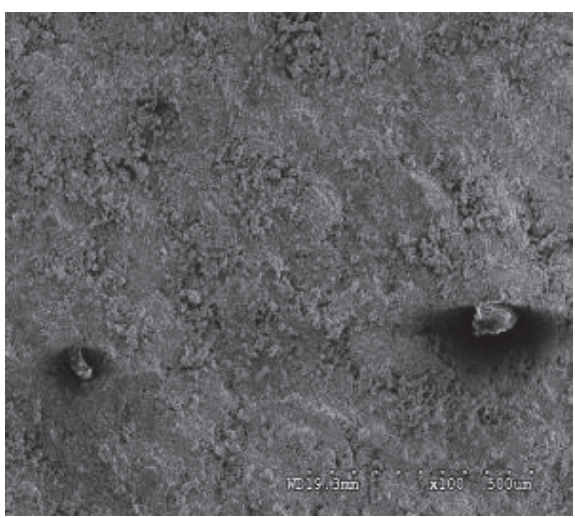

(a)

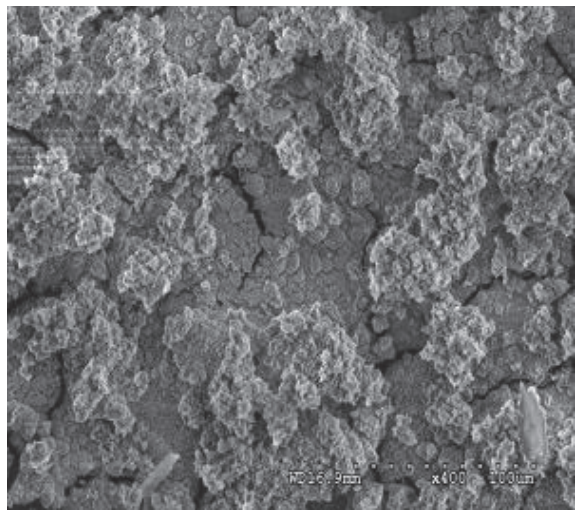

(c)

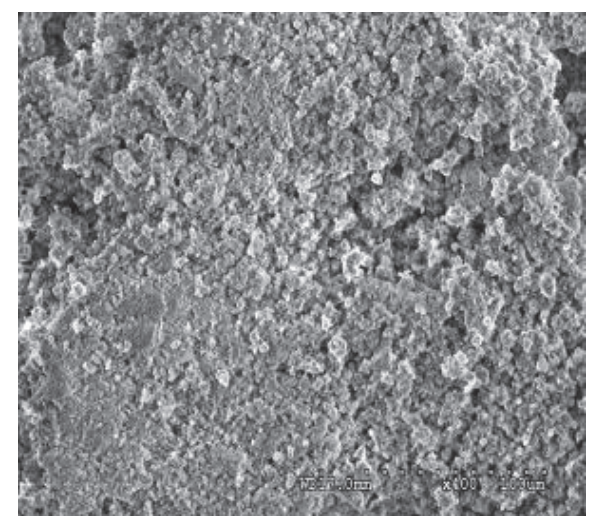

(b)

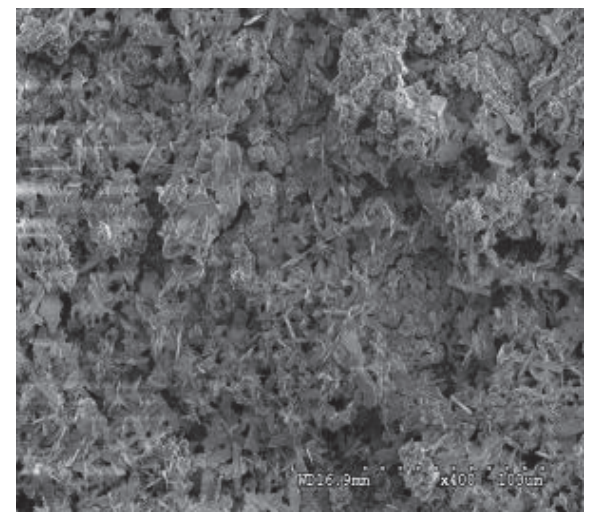

(d)

FIgURE 13: SEM micrographs of HA/GO/Pt coatings before and after corrosion tests (a, b) annealed at $200^{\circ} \mathrm{C}$ and (c, d) annealed at $600^{\circ} \mathrm{C}$.

Figure 15(b). As can be seen, the thin film electrodeposited zirconium shows better resistance against a reciprocating load (wear) when the annealing temperature increases from 200 to $300^{\circ} \mathrm{C}$. This may be due to an increase in adhesion strength between the thin film and the zirconium substrate and diffusion and penetration of the coated layer into the substrate. Moreover, hydroxyapatite in the composite coating plays as a lubricant with proper resistance to wear on the surface of the coated zirconium. Phosphate ions form hydrated ions in the thin film layer in which they turn into a large layer of hydration that results in nano/micro-ball baring lubricants between the coated substrate and the normal loads to increase the composite thin film antifriction property [35]. Nevertheless, research studies show that coatings obtain significant wear resistance with the inclusion of graphene oxide due to its high surface area and uniform dispersion 


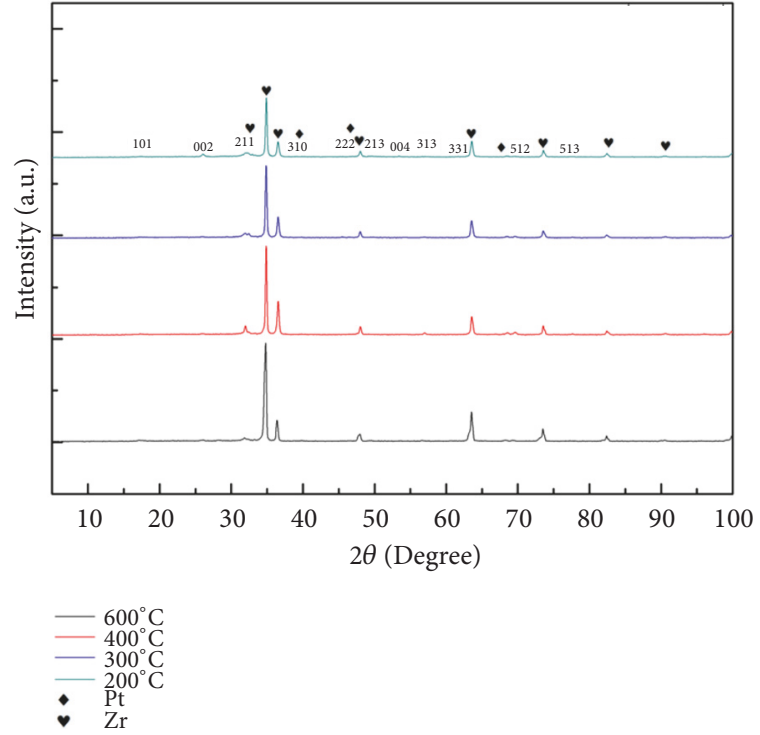

(a)
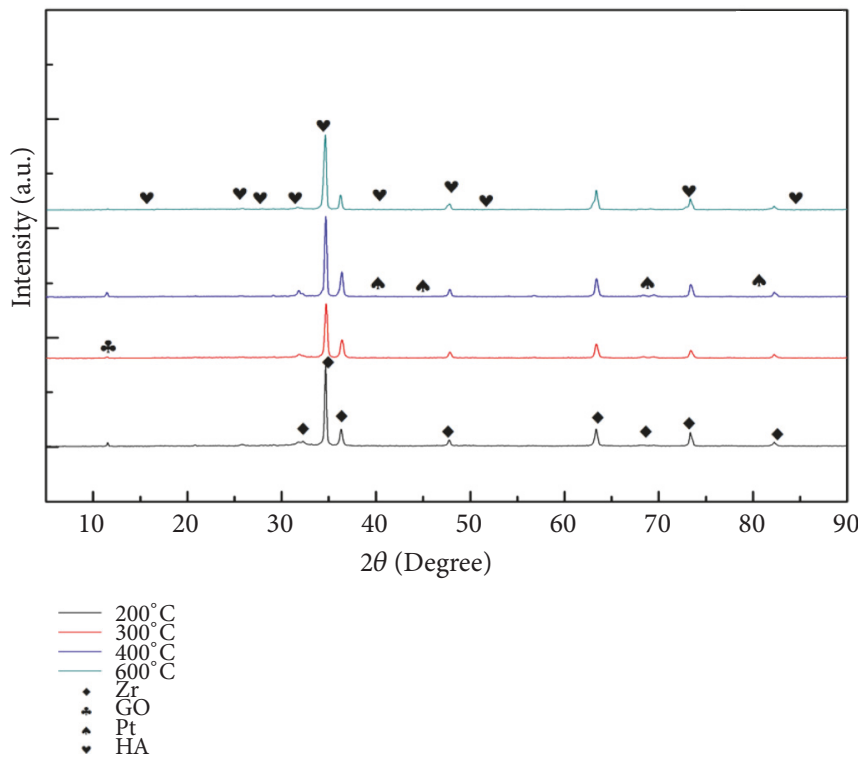

(b)

FIGURE 14: The phase analysis of the heat treated HA/GO/Pt coatings before (a) and after (b) corrosion test.

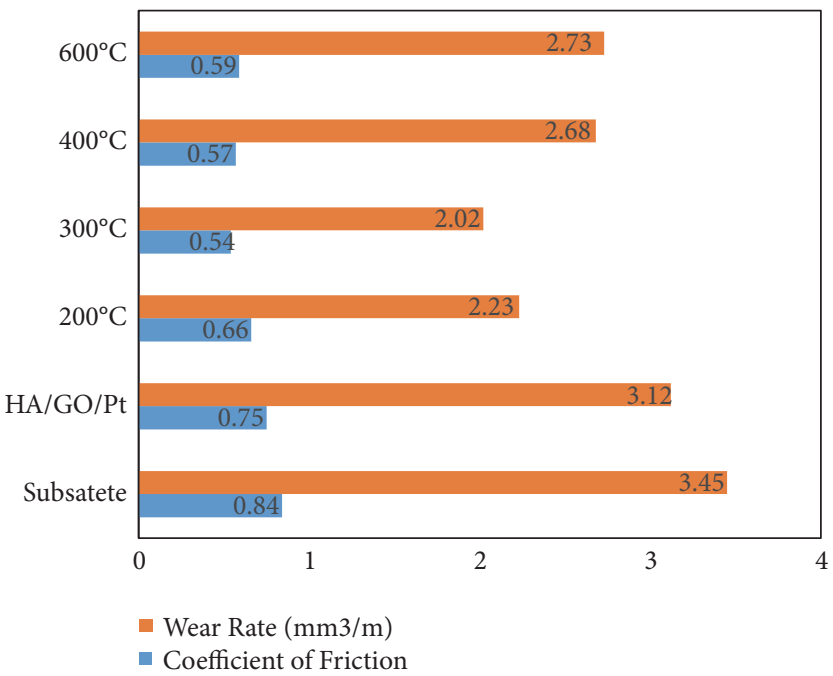

(a) $\mathrm{COF}$ and wear rate of different samples
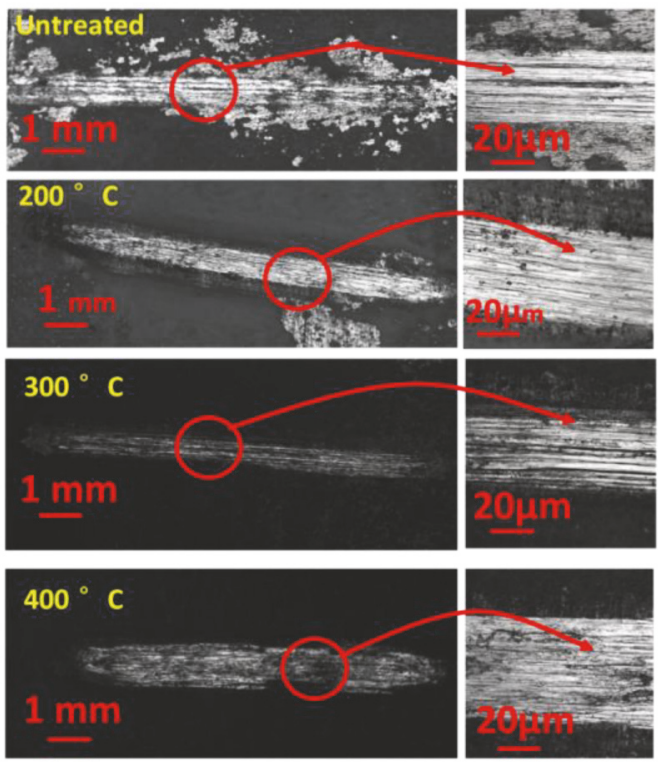

(b) Microscopic images of wear scars (at different magnifications)

Figure 15: The friction coefficient and wear loss of substrate, HA/GO/Pt coating (before annealing) and HA/GO/Pt coatings after heat treatment at different temperatures.

which lets the energy be released from its uniform sites results in high fracture toughness of the composite thin layer of coating [36]. Also, crack energy dissipation, crack bridging, and propagation of crack will be mitigated because the crack can be deflected in a composite containing graphene (This has been investigated by Kvetkova et al.) [37]. Consequently, a continuous layer of graphene oxide formation has a significant effect on $\mathrm{HA} / \mathrm{GO} / \mathrm{Pt}$ thin film's resistance against wear.
The tribological properties of electrodeposited $\mathrm{HA} / \mathrm{rGO} /$ Pd onto SST304 were studied in our previous research work [30]. The friction coefficient and wear resistance of heattreated $\mathrm{HA} / \mathrm{rGO} / \mathrm{Pd}$ deposited stainless steel 304 at versatile temperatures were investigated. The coated substrate by $\mathrm{HA} / \mathrm{rGO} / \mathrm{Pd}$ treated at $600^{\circ} \mathrm{C}$ showed a noticeably lower average COF of 0.581 compared to other specimens. When the temperature increased from 200 to $400^{\circ} \mathrm{C}$ the friction 
coefficient increased and further temperature enhancement to $600^{\circ} \mathrm{C}$ resulted in a lower friction coefficient. Nevertheless, the coating showed better resistance against wear when the temperature enhanced from 200 to $600^{\circ} \mathrm{C}$. This could be explained by diffusion of the coating into the substrate and enhance adhesion strength between the thin film and stainless steel 304 substrates. Compared to $\mathrm{HA} / \mathrm{rGO} / \mathrm{Pd}$, treated $\mathrm{HA} / \mathrm{GO} / \mathrm{Pt}$ shows similar values for COFs, although the best COF occurred at $300^{\circ} \mathrm{C}$ in this study.

\section{Conclusion}

In this study, pure zirconium was selected as the substrate and $\mathrm{HA}, \mathrm{HA} / \mathrm{GO}$, and $\mathrm{HA} / \mathrm{GO} / \mathrm{Pt}$ were the coatings deposited by electrodeposition technique. To evaluate the effect of annealing on properties of the composite coating, the HA/GO/Pt coated zirconium was heated at different annealing temperatures. A reciprocating ball on disc wear test machine was used to investigate the wear resistance of the composite coating after annealing. The coefficient of friction and wear rate of $\mathrm{HA} / \mathrm{GO} / \mathrm{Pt}$ coated substrate heated at $300^{\circ} \mathrm{C}$ were 0.54 and $2.02 \mathrm{~mm}^{3} / \mathrm{m}$ showing better results compared to the other samples heated at 200,400 , and $600^{\circ} \mathrm{C}$. Furthermore, corrosion behavior and biocompatibility of HA/GO/Pt-, HA, and HA/GO-coated zirconium were investigated. The biocompatibility result showed that the bare zirconium surface is capable of distribution of a very little number of cells. The biocompatibility experiments indicated that the coatings enhanced the cells attachments and proliferations atop the electrodeposited zirconium surface. HA/GO/Pt electrodeposited zirconium displayed insignificant cell attachment and proliferation compared to the other coatings. The electrochemical results showed that the HA/GO/Pt nanocomposite layer had better protection against corrosion compared to other coated specimens after soaking in the biomimetic synthetic medium. In addition, the electrochemical tests were conducted on the heat treated HA/GO/Pt electrodeposited zirconium and the results showed that the anodic current densities for samples annealed at $200,300,400$, and $600^{\circ} \mathrm{C}$ are lower than the nonannealed $\mathrm{HA} / \mathrm{GO} / \mathrm{Pt}$ deposited zirconium. The best corrosion result was achieved at $400^{\circ} \mathrm{C}$ with $\mathrm{I}_{\text {corr }}$ and $\mathrm{E}_{\text {corr }}$ of $1.521 \mathrm{nA}$ and $379.096 \mathrm{mV}$. This evidently proposes that utilizing $\mathrm{HA} / \mathrm{GO} / \mathrm{Pt}$ plus heat treatment reduces the risk of failure due to corrosion.

\section{Data Availability}

The data including figures, graphs, and tables used to support the findings of this study are included in the article.

\section{Conflicts of Interest}

The authors declare that they have no conflicts of interest.

\section{Acknowledgments}

We acknowledge Hanyang University's financial support through the Young Faculty Forum Fund (no. 201600000001555).

\section{References}

[1] S. Ramakrishna, J. Mayer, E. Wintermantel, and K. W. Leong, "Biomedical applications of polymer-composite materials: a review," Composites Science and Technology, vol. 61, no. 9, pp. 1189-1224, 2001.

[2] W. Pompe, H. Worch, M. Epple et al., "Functionally graded materials for biomedical applications," Materials Science and Engineering: A, vol. 362, no. 1-2, pp. 40-60, 2003.

[3] D. F. Williams, "On the mechanisms of biocompatibility," Biomaterials, vol. 29, no. 20, pp. 2941-2953, 2008.

[4] R. L. Williams, S. A. Brown, and K. Merritt, "Electrochemical studies on the influence of proteins on the corrosion of implant alloys," Biomaterials, vol. 9, no. 2, pp. 181-186, 1988.

[5] J. Blac, "Systemic effects of biomaterials", Biomaterials, vol. 5, no. 1, pp. 11-18, 1984.

[6] Y. Liu, J. Zhang, J. Wang et al., "Tailoring of the dopamine coated surface with VEGF loaded heparin/poly-l-lysine particles for anticoagulation and accelerate in situ endothelialization," Journal of Biomedical Materials Research Part A, vol. 103, no. 6, pp. 2024-2034, 2015.

[7] H. G. Wang, T. Y. Yin, S. P. Ge et al., "Biofunctionalization of titanium surface with multilayer films modified by heparin-VEGF-fibronectin complex to improve endothelial cell proliferation and blood compatibility," Journal of Biomedical Materials Research Part A, vol. 101, no. 2, pp. 413-420, 2013.

[8] Y. Leng, P. Yang, J. Chen et al., "Fabrication of Ti-O/Ti-N duplex coatings on biomedical titanium alloys by metal plasma immersion ion implantation and reactive plasma nitriding/oxidation," Surface and Coatings Technology, vol. 138, no. 23, pp. 296-300, 2001.

[9] M. J. Finley, L. Rauova, I. S. Alferiev, J. W. Weisel, R. J. Levy, and S. J. Stachelek, "Diminished adhesion and activation of platelets and neutrophils with CD47 functionalized blood contacting surfaces," Biomaterials, vol. 33, no. 24, pp. 5803-5811, 2012.

[10] E. Zalnezhad, "Effect of structural evolution on mechanical properties of ZrO2 coated Ti-6Al-7Nb-biomedical application," Applied Surface Science, vol. 370, pp. 32-39, 2016.

[11] S. Cengiz and Y. Gencer, "The characterization of the oxide based coating synthesized on pure zirconium by plasma electrolytic oxidation," Surface and Coatings Technology, vol. 242, pp. 132-140, 2014.

[12] K. Lin, C. Wu, and J. Chang, "Advances in synthesis of calcium phosphate crystals with controlled size and shape," Acta Biomaterialia, vol. 10, no. 10, pp. 4071-4102, 2014.

[13] K. S. Novoselov, A. K. Geim, S. V. Morozov et al., "Electric field effect in atomically thin carbon films," Science, vol. 306, no. 5696, pp. 666-669, 2004.

[14] J. A. Helsen and Y. Missirlis, Biomaterials: A Tantalus Experience, Springer Science and Business Media, 2010.

[15] J. W. Romesburg, P. L. Wasserman, and C. H. Schoppe, "Metallosis and Metal-induced synovitis following total knee arthroplasty: review of radiographic and CT findings," Journal of Radiology Case Reports, vol. 4, no. 9, pp. 7-17, 2010.

[16] G. Mabilleau, Y.-M. Kwon, H. Pandit, D. W. Murray, and A. Sabokbar, "Metal-on-metal hip resurfacing arthroplasty: a review of periprosthetic biological reactions," Acta Orthopaedica, vol. 79, no. 6, pp. 734-747, 2008.

[17] H. N. Lim, N. M. Huang, S. S. Lim, I. Harrison, and C. H. Chia, "Fabrication and characterization of graphene hydrogel via hydrothermal approach as a scaffold for preliminary study 
of cell growth," International Journal of Nanomedicine, vol. 6, pp. 1817-1823, 2011.

[18] S. Baradaran, E. Moghaddam, W. J. Basirun et al., "Mechanical properties and biomedical applications of a nanotube hydroxyapatite-reduced graphene oxide composite," Carbon, vol. 69 , pp. 32-45, 2014.

[19] E. Zalnezhad, A. M. S. Hamouda, J. Jaworski, and Y. Do Kim, "From zirconium nanograins to zirconia nanoneedles," Scientific Reports, vol. 6, 2016.

[20] A. Jankovic, S. Erakovic, M. Vukainovic-Sekulic, V. MikovicStankovic, S. J. Park, and K. Y. Rhee, "Graphene-based antibacterial composite coatings electrodeposited on titanium for biomedical applications," Progress in Organic Coatings, vol. 83, pp. 1-10, 2015.

[21] A. Jankovic, S. Erakovic, M. Mitric et al., "Bioactive hydroxyapatite/graphene composite coating and its corrosion stability in simulated body fluid," Journal of Alloys and Compounds, vol. 624, pp. 148-157, 2015.

[22] T. Szatkowski, A. Kołodziejczak-Radzimska, J. Zdarta et al., "Synthesis and characterization of hydroxyapatite/chitosan composites," Physicochemical Problems of Mineral Processing, vol. 51, no. 2, pp. 575-585, 2015.

[23] F. A. López, A. L. R. Mercê, F. J. Alguacil, and A. López-Delgado, "A kinetic study on the thermal behaviour of chitosan," Journal of Thermal Analysis and Calorimetry, vol. 91, no. 2, pp. 633-639, 2008.

[24] L. Cordero-Arias, S. Cabanas-Polo, H. Gao et al., "Electrophoretic deposition of nanostructured-TiO2/chitosan composite coatings on stainless steel," RSC Advances, vol. 3, no. 28, pp. 11247-11254, 2013.

[25] S. Tang, B. Tian, Y. J. Guo, Z. A. Zhu, and Y. P. Guo, "Chitosan/carbonated hydroxyapatite composite coatings: fabrication, structure and biocompatibility," Surface and Coatings Technology, vol. 251, pp. 210-216, 2014.

[26] F. Gebhardt, S. Seuss, M. C. Turhan, H. Hornberger, S. Virtanen, and A. R. Boccaccini, "Characterization of electrophoretic chitosan coatings on stainless steel," Materials Letters, vol. 66, no. 1, pp. 302-304, 2012.

[27] J. Reyes-Gasga, E. L. Martínez-Piñeiro, G. Rodríguez-Álvarez, G. E. Tiznado-Orozco, R. García-García, and E. F. Brès, "XRD and FTIR crystallinity indices in sound human tooth enamel and synthetic hydroxyapatite," Materials Science and Engineering C: Materials for Biological Applications, vol. 33, no. 8, pp. 4568-4574, 2013.

[28] Y. Liu, J. Huang, and H. Li, "Synthesis of hydroxyapatite-reduced graphite oxide nanocomposites for biomedical applications: oriented nucleation and epitaxial growth of hydroxyapatite," Journal of Materials Chemistry B, vol. 1, no. 13, pp. 18261834, 2013.

[29] D. Gopi, S. Nithiya, E. Shinyjoy, and L. Kavitha, "Spectroscopic investigation on formation and growth of mineralized nanohydroxyapatite for bone tissue engineering applications," Spectrochimica Acta, Part A: Molecular and Biomolecular Spectroscopy, vol. 92, pp. 194-200, 2012.

[30] H. F. S. G. A. Yafei, K. Uzun, F. Musharavati et al., "HA/rGO/Pd nanocomposite thin film coating on SST 304 - Synthesize, characterization, and properties investigations," Journal of Alloys and Compounds, vol. 741, pp. 562-574, 2018.

[31] K. Y. Rhee, S. Eraković, A. Janković et al., "In vitro investigation of electrophoretically deposited bioactive hydroxyapatite/chitosan coatings reinforced by graphene," Journal of Industrial and Engineering Chemistry, vol. 47, pp. 336-347, 2017.
[32] M. S. Djošić, M. Mitrić, and V. B. Mišković-Stankovic, “The porosity and roughness of electrodeposited calcium phosphate coatings in simulated body fluid," Journal of the Serbian Chemical Society, vol. 80, no. 2, pp. 237-251, 2015.

[33] C. Liu, J. Zhang, E. Yifeng, J. Yue, L. Chen, and D. Li, “One-pot synthesis of graphene-chitosan nanocomposite modified carbon paste electrode for selective determination of dopamine," Electronic Journal of Biotechnology, vol. 17, no. 4, pp. 183-188, 2014.

[34] Y. Y. Shi, M. Li, Q. Liu et al., "Electrophoretic deposition of graphene oxide reinforced chitosan-hydroxyapatite nanocomposite coatings on Ti substrate," Journal of Materials Science: Materials in Medicine, vol. 27, no. 3, article 48, 2016.

[35] S. Ban and S. Maruno, "Morphology and microstructure of electrochemically deposited calcium phosphates in a modified simulated body fluid," Biomaterials, vol. 19, no. 14, pp. 1245-1253, 1998.

[36] Y. Xie, H. Li, C. Ding, X. Zheng, and K. Li, "Effects of graphene plates' adoption on the microstructure, mechanical properties, and in vivo biocompatibility of calcium silicate coating," International Journal of Nanomedicine, vol. 10, pp. 3855-3863, 2015.

[37] L. Kvetková, A. Duszová, P. Hvizdoš, J. Dusza, P. Kun, and C. Balázsi, "Fracture toughness and toughening mechanisms in graphene platelet reinforced $\mathrm{Si} 3 \mathrm{~N} 4$ composites," Scripta Materialia, vol. 66, no. 10, pp. 793-796, 2012. 


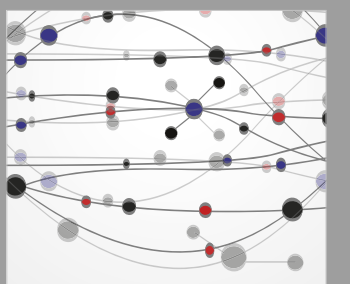

The Scientific World Journal
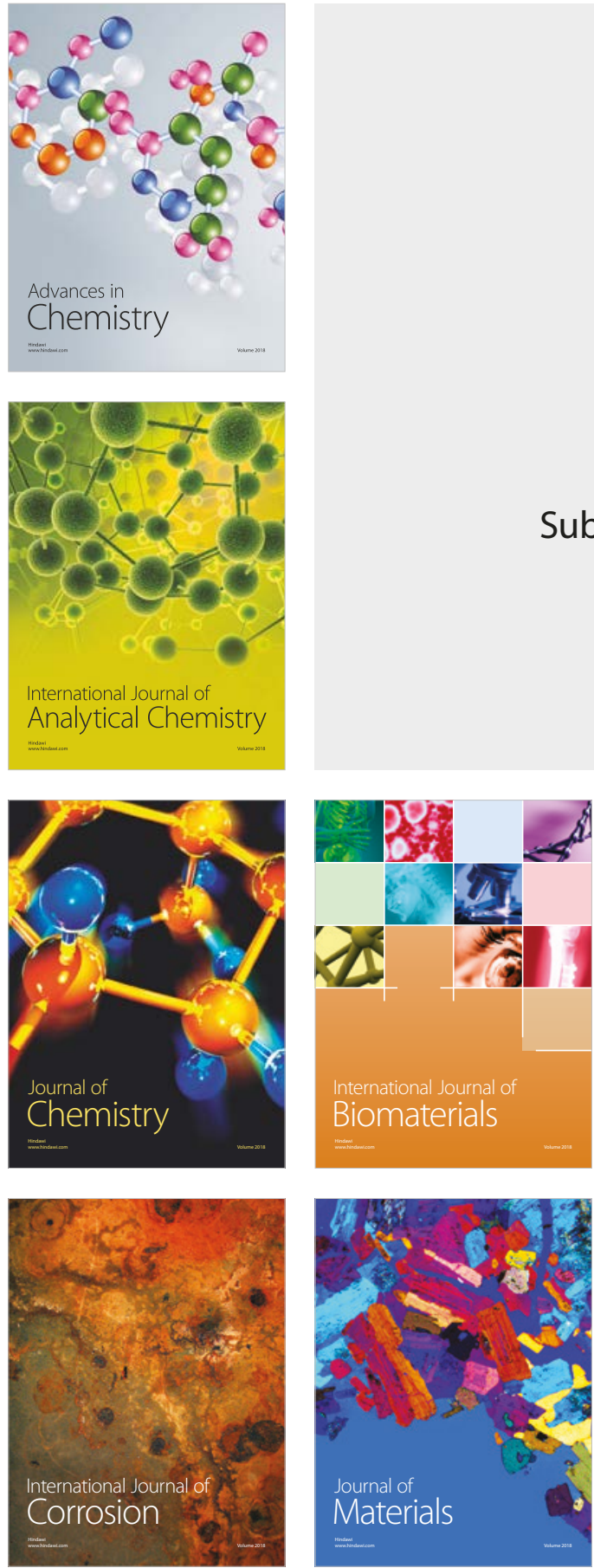

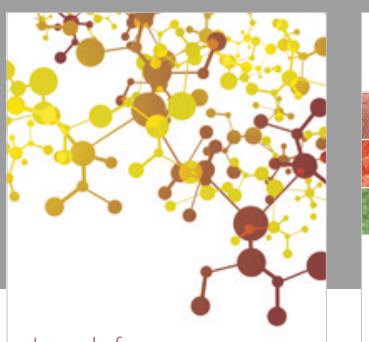

Journal of

Applied Chemistry
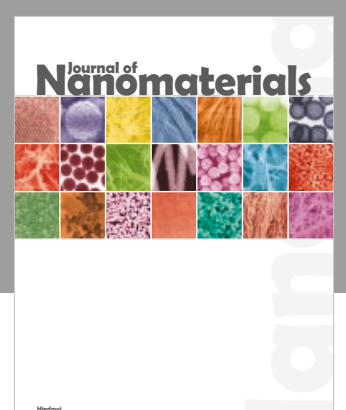

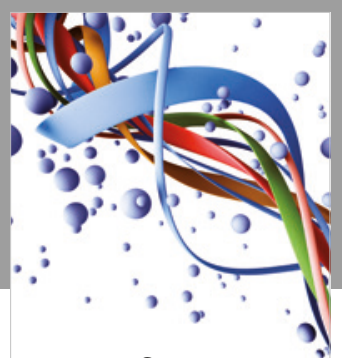

Scientifica

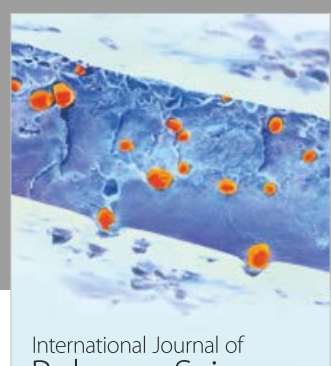

Polymer Science

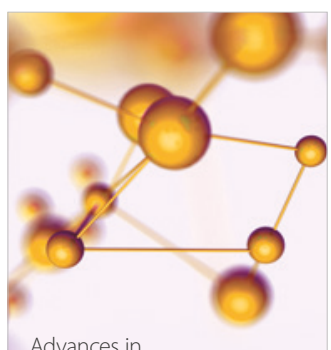

Physical Chemistry
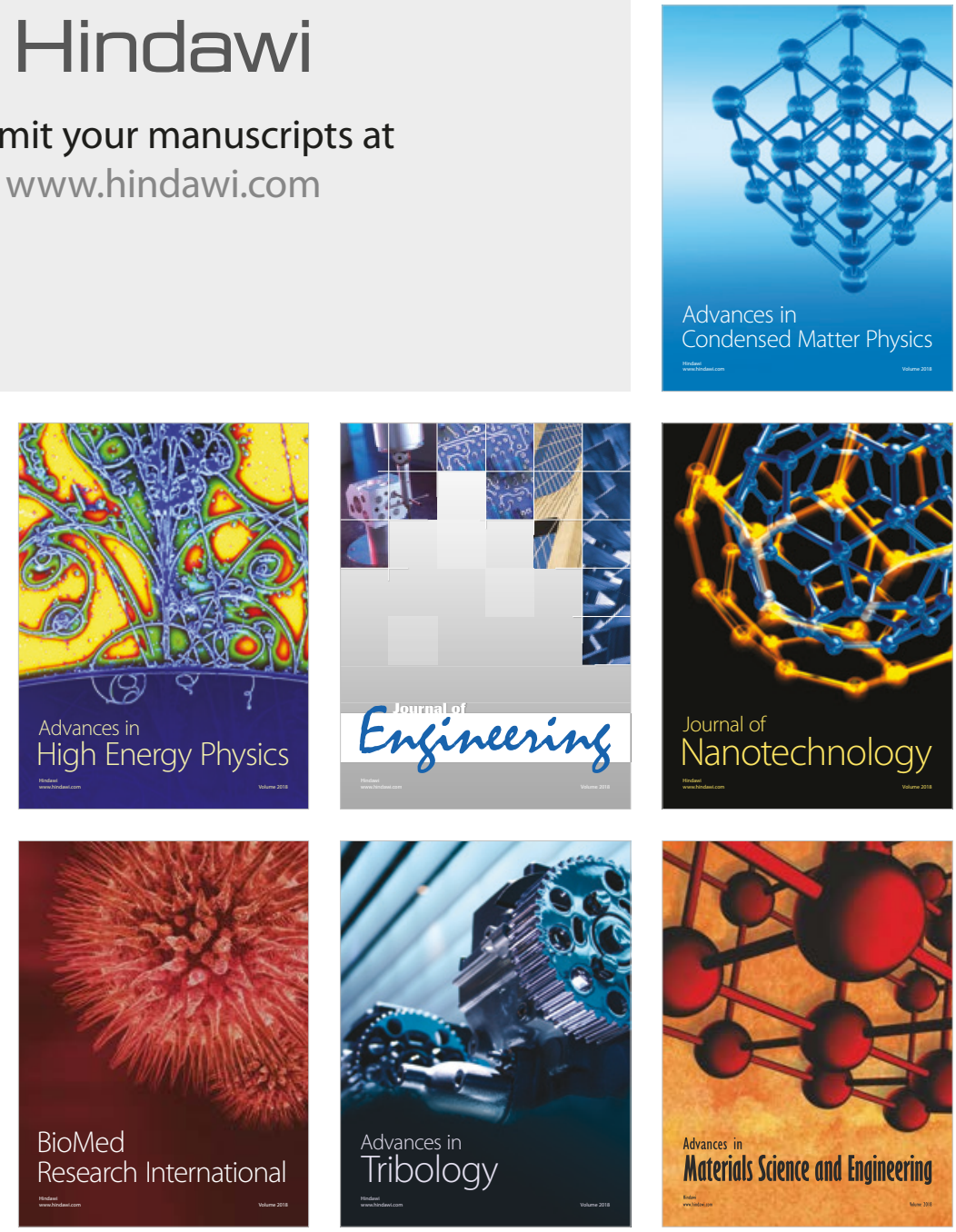